\title{
The Neuromuscular Junction and Wide Heterogeneity of Congenital Myasthenic Syndromes
}

\author{
Pedro M. Rodríguez Cruz ${ }^{1,2, *}$, Jacqueline Palace ${ }^{1}$ and David Beeson ${ }^{1,2}$ (1) \\ 1 Nuffield Department of Clinical Neurosciences, University of Oxford, Oxford OX3 9DU, UK; \\ Jacqueline.palace@ndcn.ox.ac.uk (J.P.); David.beeson@ndcn.ox.ac.uk (D.B.) \\ 2 Neurosciences Group, Weatherall Institute of Molecular Medicine, University of Oxford, \\ The John Radcliffe Hospital, Oxford OX3 9DS, UK \\ * Correspondence: pedro.rodriguezcruz@ndcn.ox.ac.uk; Tel.: +44-1865-231-915
}

Received: 23 April 2018; Accepted: 21 May 2018; Published: 5 June 2018

\begin{abstract}
Congenital myasthenic syndromes (CMS) are genetic disorders characterised by impaired neuromuscular transmission. This review provides an overview on CMS and highlights recent advances in the field, including novel CMS causative genes and improved therapeutic strategies. CMS due to mutations in SLC5A7 and SLC18A3, impairing the synthesis and recycling of acetylcholine, have recently been described. In addition, a novel group of CMS due to mutations in SNAP25B, $S Y T 2, V A M P 1$, and UNC13A1 encoding molecules implicated in synaptic vesicles exocytosis has been characterised. The increasing number of presynaptic CMS exhibiting CNS manifestations along with neuromuscular weakness demonstrate that the myasthenia can be only a small part of a much more extensive disease phenotype. Moreover, the spectrum of glycosylation abnormalities has been increased with the report that GMPPB mutations can cause CMS, thus bridging myasthenic disorders with dystroglycanopathies. Finally, the discovery of COL13A1 mutations and laminin $\alpha 5$ deficiency has helped to draw attention to the role of extracellular matrix proteins for the formation and maintenance of muscle endplates. The benefit of $\beta 2$-adrenergic agonists alone or combined with pyridostigmine or 3,4-Dyaminopiridine is increasingly being reported for different subtypes of CMS including AChR-deficiency and glycosylation abnormalities, thus expanding the therapeutic repertoire available.
\end{abstract}

Keywords: congenital myasthenic syndromes; neuromuscular junction; neuromuscular transmission; presynaptic CMS; COL13A1; SNARE complex; N-glycosylation pathway; GMPPB; $\beta 2$-adrenergic agonists

\section{Introduction}

Congenital myasthenic syndromes (CMS) are genetic disorders characterised by impaired neuromuscular transmission [1]. CMS is a rare condition with an estimated prevalence of genetically confirmed cases of approximately 9.2 cases per million children under 18 years of age in the UK [2]. All subtypes of CMS share the clinical feature of fatigable muscle weakness, but age at onset, presenting symptoms, distribution of weakness, and response to treatment vary, depending on the molecular mechanism that results from the underlying genetic defect. Most common classification of CMS relies on the location of the mutated protein (Figure 1). 


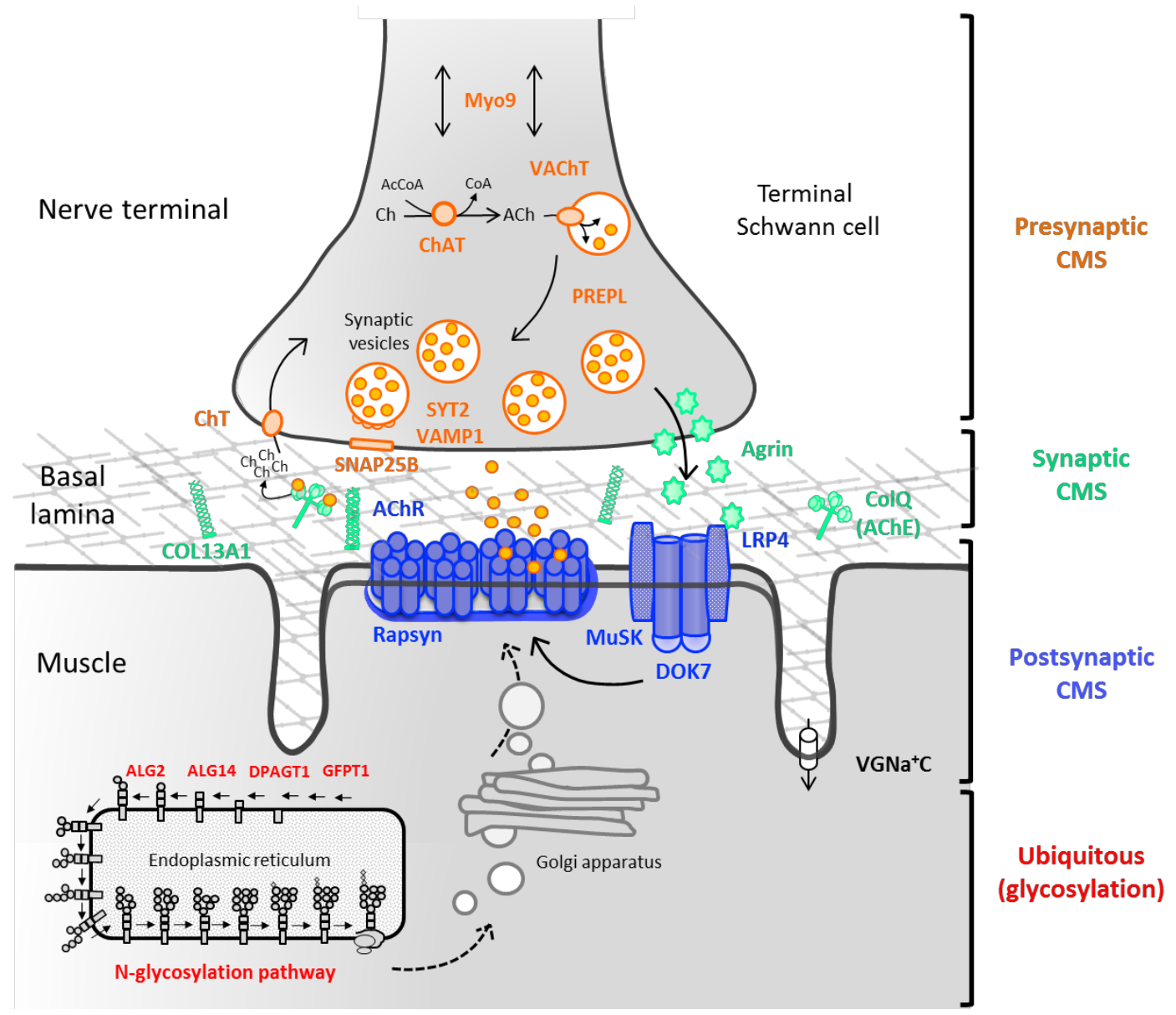

Figure 1. Schematic of the neuromuscular junction (NMJ) and the main molecules involved in congenital myasthenic syndromes. CMS result from presynaptic (ChAT, ChT, MUNC13-1, MYO9, PREPL, SYT2, VAChT, and VAMP1), synaptic basal lamina (COLQ and COL13A1), and postsynaptic defects (AChR subunits: $\alpha, \beta, \delta$ and $\varepsilon, A G R N$, DOK7, MUSK, LRP4, and rapsyn). An increasing number of presynaptic CMS is being reported due to abnormalities in the synthesis, recycling or release of acetylcholine (normal arrows). The Agrin-LRP4-MuSK signaling pathway (bold arrows) is crucial for the clustering of the AChRs at the postsynaptic muscle membrane. Novel genes encoding for ubiquitous molecules (GFPT1, DPAGT1, ALG2, ALG14, and GMPPB) are represented in the endoplasmic reticulum (ER) in a simplified view of the $N$-glycosylation pathway. Post-translational modifications of the saccharide structure of the AChR and other NMJ proteins take place at the ER and Golgi apparatus (dashed arrows), before reaching the muscle cell surface as mature proteins. ACh, acetylcholine; AChE, acetylcholinesterase; AcCoA, acetyl coenzyme A; Ch, choline; VGNa + C, voltage-gated sodium channel.

The clinical diagnosis of CMS is based on the presence of fatigable muscle weakness (usually from an early age) in conjunction with abnormal findings on neurophysiological studies, in particular decremental response greater than $10 \%$ on repetitive nerve stimulation (RNS) or abnormal jitter and/or blocking on single-fibre electromyography (SFEMG), and positive response to pharmacological treatment. It is important to understand that although most patients have symptoms from birth or early childhood, some do present later in life during teenage years or adulthood. The classic myasthenic phenotype exhibits weakness of the ocular and facial muscles, but certain subtypes can present with apnoeic episodes or isolated limb-girdle weakness, thus increasing the diagnostic challenge.

Testing for antibodies against the acetylcholine receptor (AChR) and the muscle-specific kinase (MuSK) is useful to rule out myasthenia gravis (MG). However, negative results do not always exclude 
the presence of antibodies to the neuromuscular junction (NMJ) since novel targets have been recently identified $[3,4]$ and antibody testing is not always readily available. An additional challenge are patients whose $\mathrm{AChR}$ antibody titre is negative on the classic radioimmunoprecipitation assay (RIA) but are positive for antibodies to clustered AChRs using a cell-based assay (CBA) [5]. Further complexity is encountered where congenital myopathies associate with secondary neuromuscular transmission abnormalities [6].

The genetic diagnosis of CMS is complex due to the existence of more than 30 CMS causative genes identified to date (Table 1). This number is likely to increase in the future due to the wider availability of next-generation sequencing (NGS). Features of the phenotype that help to tailor genetic screening include age at onset, distribution of weakness, electromyographic findings, and response to treatment (Figure 2). Recent insight has shown that patients with presynaptic CMS and with abnormalities within the glycosylation pathway may manifest with symptoms beyond the neuromuscular boundaries. Providing the appropriate symptomatic treatment requires the genetic subtype to be identified because treatments useful in some CMS subtypes can make other patients weaker. Furthermore, identifying a genetic cause for myasthenic weakness can help to avoid unnecessary immunosuppression and thymectomy.

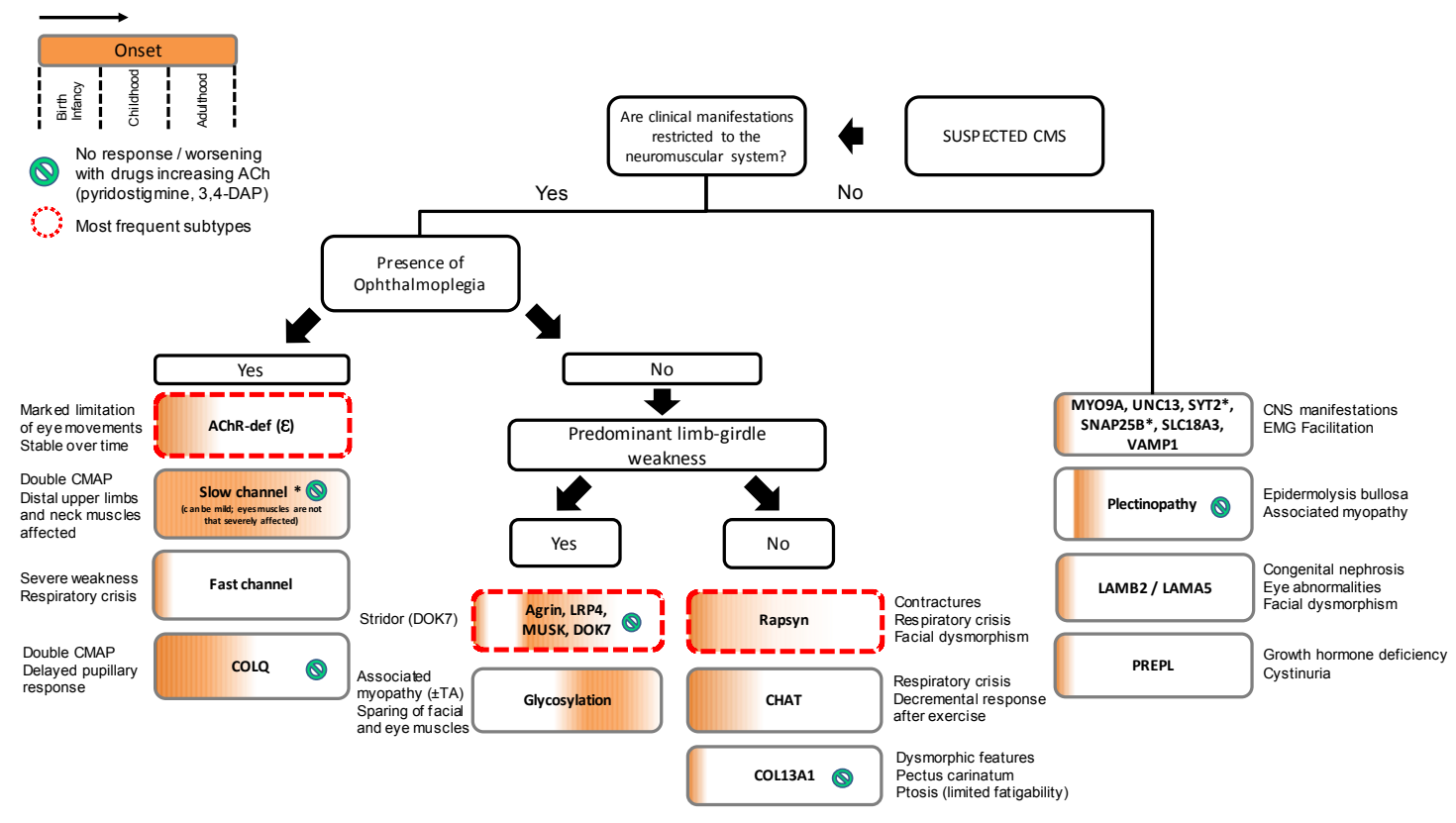

Figure 2. Proposed algorithm for targeted genetic screening of suspected CMS cases. Clinical evaluation should start by exploring age at onset and presence of manifestations beyond the neuromuscular boundaries. Ophthalmoplegia and limb-girdle weakness are clinically useful to guide genetic screening. Key diagnostic features are provided outside the boxes. Most frequent subtypes of CMS include AChR-deficiency, DOK7 CMS, and rapsyn CMS which stand for approximately $70 \%$ of all cases in the UK. $\left(^{*}\right)$ Slow channel syndrome, SYT2 CMS, and SNAP25B CMS are dominantly inherited. CNS, central nervous system; TA, tubular aggregates. 
Table 1. CMS subtypes and associated genes

\begin{tabular}{|c|c|}
\hline CMS Subtype & Gene \\
\hline \multicolumn{2}{|c|}{ Proteins with defined NMJ function } \\
\hline \multicolumn{2}{|l|}{ Presynaptic } \\
\hline Choline $O$-Acetyltransferase & CHAT \\
\hline Unconventional myosin 9 & MYO9A \\
\hline PREPL & PREPL \\
\hline Vesicular ACh transporter (VAChT) & SLC18A3 \\
\hline High-affinity choline transporter 1 (ChT) & SLC5A7 \\
\hline Synaptosome Associated Protein 25 & SNAP25B \\
\hline Synaptotagmin 2 & SYT2 \\
\hline MUNC13-1 & UNC13-1 \\
\hline Synaptobrevin 1 & VAMP1 \\
\hline \multicolumn{2}{|l|}{ Synaptic } \\
\hline Collagen Type XIII $\alpha 1$ Chain & COL13A1 \\
\hline Endplate AChE deficiency & COLQ \\
\hline Laminin $\alpha 5$ deficiency & $L A M A 5$ \\
\hline Laminin $\beta 2$ deficiency & $L A M B 2$ \\
\hline \multicolumn{2}{|l|}{ Postsynaptic } \\
\hline Agrin (neuronal) & $A G R N$ \\
\hline Primary AChR deficiency & CHRNA, CHRNB, CHRND, CHRNE \\
\hline Slow channel syndrome & CHRNA, CHRNB, CHRND, CHRNE \\
\hline Fast channel syndrome & CHRNA, CHRNB, CHRND, CHRNE \\
\hline Low conductance syndrome & CHRNE \\
\hline Escobar syndrome & CHRNG \\
\hline DOK7 & DOK7 \\
\hline LRP4 & $L R P 4$ \\
\hline MuSK & MUSK \\
\hline Plectin deficiency & PLEC1 \\
\hline Rapsyn & RAPSN \\
\hline Sodium channel myasthenia & $S C N 4 A$ \\
\hline \multicolumn{2}{|c|}{ Ubiquitously expressed proteins } \\
\hline ALG2 & $A L G 2$ \\
\hline ALG14 & ALG14 \\
\hline DPAGT1 & DPAGT1 \\
\hline GFPT1 & GFPT1 \\
\hline GMPPB & $G M P P B$ \\
\hline SLC25A1 & SCL25A1 \\
\hline
\end{tabular}

ALG2, $\alpha-\overline{1,3 / 1,6-m a n n o s y l t r a n s f e r a s e ; ~ A L G 14, ~ U D P-~} N$-acetylglucosaminyltransferase subunit; $\quad$ DOK7, docking protein 7; DPAGT1, dolichyl-phosphate $N$-acetylglucosaminephosphotransferase 1; GFPT1, glutamine-fructose-6-phosphate transaminase 1; GMPPB, GDP-mannose pyrophosphorylase B; LRP4, LDL receptor related protein 4; MuSK, Muscle specific kinase; PREPL, prolyl endopeptidase-like gene; SLC25A1, solute carrier family 25 member 1.

\section{Presynaptic Syndromes}

The number of CMS subtypes caused by mutations in genes encoding presynaptic proteins has expanded in recent years thanks to the use of NGS (Figure 3). These can be subdivided depending on the pathogenic mechanism into disorders affecting axonal transport, the synthesis and recycling of $\mathrm{ACh}$, and the exocytosis of synaptic vesicles. A considerable proportion of patients in this group present with early onset severe disease, episodic apnoeas, and central deficits derived from the expression of the encoded proteins within the central nervous system. This represents a novel aspect in CMS, where previously clinical manifestations were considered to be largely restricted to the NMJ. 


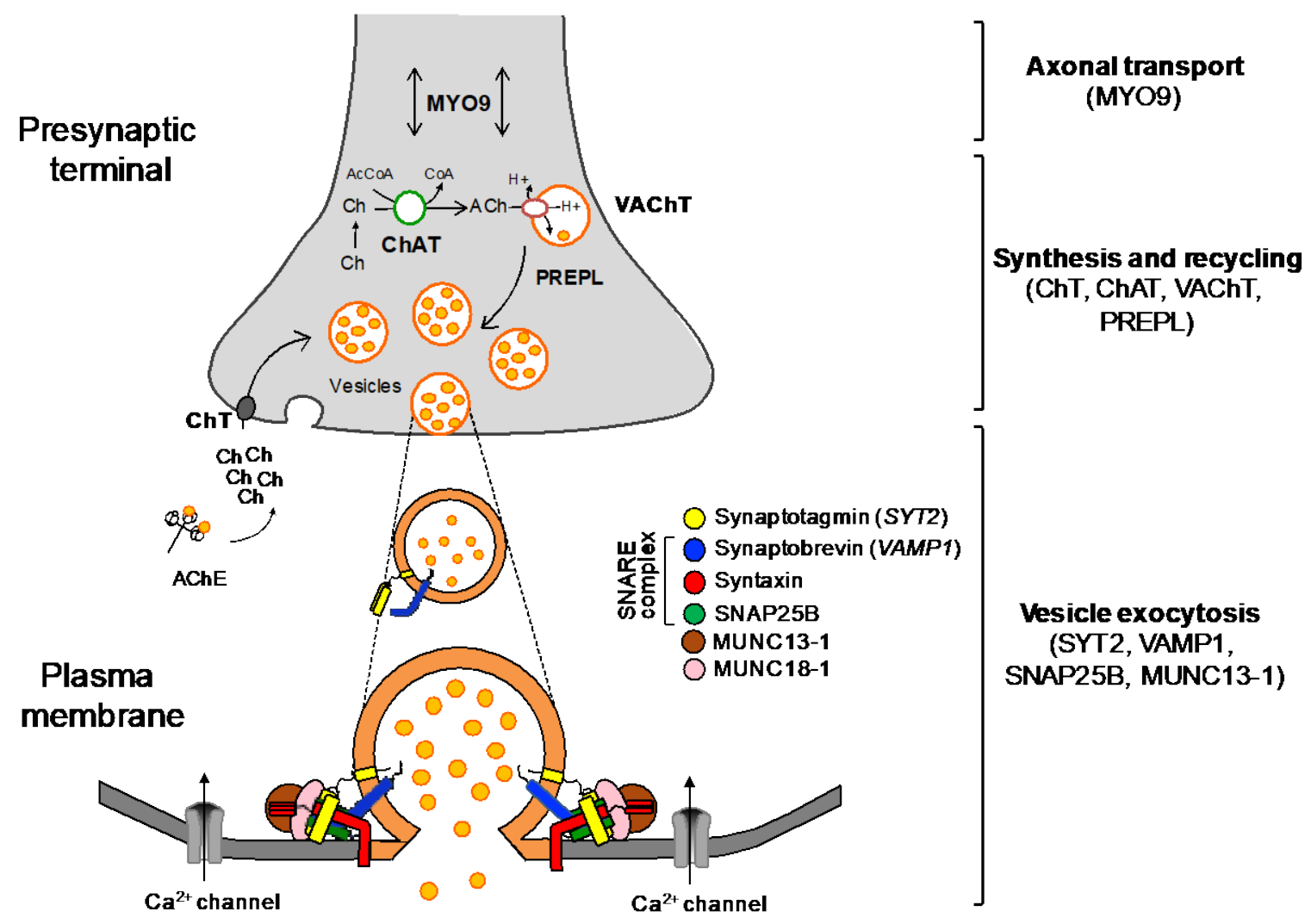

Active zone

Figure 3. Schematic representation of the nerve terminal and the main molecules involved in presynaptic CMS. In the synaptic cleft, acetylcholinesterase (AChE) breaks down acetylcholine (ACh) into acetate and choline $(\mathrm{Ch})$, which is uptaken by the sodium-dependent high-affinity choline transporter $1(\mathrm{ChT})$ to the presynaptic terminal. The enzyme choline acetyltransferase (ChAT) catalyses the synthesis of ACh from acetyl coenzyme A (AcCoA) and choline, and the vesicular acetylcholine transporter (VAChT) loads ACh into synaptic vesicles. PREPL encodes a protein that is meant to act as an effector of the clathrin-associated adaptor protein 1 in the trafficking of VAChT [7]. The synaptic vesicles accumulate adjacent to the nerve terminal ready for exocytosis. Upon the arrival of an action potential, voltage-dependent $\mathrm{Ca}^{2+}$ channels open and the influx of $\mathrm{Ca}^{2+}$ cause the fusion of vesicles to the plasma membrane through the soluble $N$-ethylmaleimide-sensitive factor attachment protein receptor (SNARE) complex (synaptobrevin, syntaxin, and SNAP25B) and the $\mathrm{Ca}^{2+}$ sensor, synaptotagmin. Additionally, MUNC 13-1 and MUNC 18-1 (syntaxin-binding protein 1) take part in the assembly and disassembly of the complex through mechanisms still not fully understood [8]. Myosin-IX A is believed to be involved in axonal transport (two directions arrow). Adapted from [9].

\subsection{Axonal Transport}

\section{MYO9A}

MYO9A encodes myosin-IXA, which belongs to the superfamily of unconventional myosins [10]. These proteins are expressed in peripheral neurons and might play a role in axonal transport [11]. A recent study has reported three patients from two kinships with missense heteroallelic mutations in MYO9A [12]. All patients had severe neonatal onset with ptosis, hypotonia, and respiratory and bulbar involvement. Additional features included developmental delay, nystagmus and oculomotor apraxia. Treatment with pyridostigmine and 3,4-diaminopyridine was beneficial. Knockdown of MYO9A in zebrafish produced defects in neuronal branching and axon guidance suggesting a role in the integrity of the presynaptic terminal. 


\subsection{Synthesis and Recycling of Acetylcholine}

\subsubsection{ChAT}

Until recent years, mutations in CHAT were the only cause of presynaptic CMS. The enzyme choline acetyltransferase (ChAT) is responsible for the synthesis of acetylcholine from acetyl coenzyme A and choline in cholinergic neurons. The pathogenic mechanisms of CHAT mutations include low expression of ChAT, abnormal catalytic efficiency and compromise in thermal stability [13]. There are no apparent abnormalities in the NMJ structure [14]. The classic phenotype is neonatal onset CMS with life-threatening apnoeic crisis [15]. Some patients develop cerebral atrophy, most likely related to hypoxic episodes, although the effect of ChAT deficiency in the CNS cannot be ruled out. More recently, patients with onset of apnoeic episodes during infancy or early childhood and a milder course between crisis have been reported [16]. Treatment with pyridostigmine might help to prevent apnoeic episodes.

\subsubsection{PREPL Deficiency}

The prolyl-endopeptidase-like gene (PREPL) encodes a protein that belongs to the prolyl-oligopeptidase subfamily of serine peptidases [17]. PREPL is ubiquitously expressed, although highest levels are reported in the brain, kidney, and muscle [18]. PREPL acts as an effector of the clathrin-associated adaptor protein 1 in the trafficking of the vesicular ACh transporter [19]. Hypotonia-cystinuria syndrome (HCS) associated with combined mutations in PREPL and SLC3A1 (a contiguous gene to PREPL on chromosome 2p21) comprises type A cystinuria, growth hormone deficiency, and fatigable muscle weakness [7]. To date, a single CMS patient due to isolated PREPL deficiency has been reported [20]. The subject had severe hypotonia and feeding difficulties at birth with positive response to AChE inhibitors. The endplate study revealed normal endplate geometry, AChR density and kinetics, but reduced postsynaptic response [20].

\subsubsection{SLC5A7}

SLC5A7 encodes the presynaptic sodium-dependent high-affinity choline transporter 1 (ChT), which uptakes choline to the presynaptic terminal after the breakdown of ACh by AChE in the synaptic cleft [21]. There is a single report to date of SLC5A7 loss-of-function mutations in seven individuals from six unrelated families [22]. Four subjects had a neonatal onset CMS with episodic apnoeas and positive response to $\mathrm{AChE}$ inhibitors while two had a more severe disease with arthrogryposis, malformations, and early death. Three patients suffered from cognitive delay. Ultrastructural analysis showed the presence of small nerve terminals and empty synaptic gutters.

\subsubsection{SLC18A3}

SLC18A3 encodes the vesicular acetylcholine transporter (VAChT), which loads ACh into synaptic vesicles in neurons [23]. Mutations in SLC18A3 were first reported in two patients with episodic apnoeas, bilateral ptosis, and ophthalmoplegia. [24]. Additional features included learning difficulties and left ventricular dysfunction. The individual compound heterozygous for p.Gly186Ala and a genomic deletion in SLC18A3 was able to walk independently at age 14 years and had positive response to pyridostigmine. The individual homozygous for p.Asp298His lost independent ambulation at five years of age. A second report described two siblings carrying a homozygous p.Gly360Arg substitution characterised by extreme hypotonia, breathing difficulties, microcephaly, and developmental delay [25]. One sibling died from respiratory failure five days after birth, and the other needed constant mechanical ventilation.

\subsection{Synaptic Vesicles Exocytosis}

This is a novel group of CMS caused by mutations in genes encoding proteins involved in synaptic vesicles exocytosis. Most comprise the soluble $\mathrm{N}$-ethylmaleimide-sensitive factor attachment protein 
receptor (SNARE) complex and related proteins [26], which are involved in the docking and $\mathrm{Ca}^{2+}$ triggered fusion of synaptic vesicles with the presynaptic membrane at both central and neuromuscular synapses. Therefore, is not surprising that patients exhibit evident central manifestations and it is debatable whether myasthenia should really be their defining characteristic since it is only a small part of a severe wider phenotypic spectrum. Clinical neurophysiology can show post-exercise amplitude facilitation as seen in LEMS [27].

\subsubsection{SNAP25}

SNAP25 codifies the synaptosomal-associated protein 25, a core element of the SNARE-complex [28,29]. A single case of SNAP25 deficiency causing CMS has been reported to date [30]. The patient harboured the p.Ile67Asn de novo dominant mutation that was shown to inhibit synaptic vesicle exocytosis in vitro. The patient had multiple contractures and breathing difficulties at birth, achieving limited walking from seven years of age. Additional features included severe developmental delay, cortical hyperexcitability, and ataxic gait. Treatment with 3,4-DAP was beneficial.

\subsubsection{SYT2}

SYT2 encodes the synaptic vesicle membrane protein Synaptotagmin 2, which serves as a $\mathrm{Ca}^{2+}$ sensor for the exocytosis of synaptic vesicles [31]. Dominant mutations in SYT2 (p.Asp307Ala and p.Pro308Leu) were first reported in two kinships featuring a non-progressive motor neuropathy and a presynaptic syndrome resembling LEMS [32]. The individuals suffered from foot deformities from childhood and a variable degree of proximal and distal weakness that improved with rest. Treatment with 3,4-DAP produced clinical and neurophysiological improvement [33].

\subsubsection{VAMP1}

VAMP1 encodes the vesicle associated membrane protein 1 (synaptobrevin 1), which is part of the SNARE complex, and has an essential role in $\mathrm{Ca}^{2+}$-triggered ACh release at the NMJ [34]. synaptobrevin 1 is also expressed in the brain, but in a less abundant manner than the highly homologous isoform synaptobrevin 2 [35]. Only four patients with CMS due to VAMP1 mutations have been reported to date in two different kinships [36]. All patients suffered from a severe condition with hypotonia, muscle weakness and feeding difficulties at birth. Symptoms improved on pyridostigmine.

\subsubsection{UNC13A1}

UNC13A1 encodes MUNC13-1 (mammalian uncoordinated-13) protein, which plays a role in the priming of synaptic vesicles into a fusion competent state [37]. The only patient with UNC13A1 mutations reported to date was homozygous for p.Gln102*, which eliminates the syntaxin 1B binding site of Munc13-1 [38]. The patient had a very severe phenotype with profound hypotonia and permanent need of ventilator support, and died at age 50 months from respiratory failure. There was no apparent clinical response to pyridostigmine or 3,4-DAP. Additional features included the presence of an abnormally thin corpus callosum in brain magnetic resonance imaging.

\section{Synaptic and Basal-Lamina Associated Syndromes}

The basal lamina of the NMJ is a structured form of extracellular matrix located at the synaptic cleft that is essential for the alignment, organization, and maintenance of pre- and postsynaptic structures [39]. The main components of the basal lamina are laminins, collagens, heparan sulfate proteoglycans (muscle agrin and perlecan), and nidogens [40] (Figure 4). Until recently, mutations in COLQ were the only CMS subtype in this category. Although other basal-lamina associated CMS have been recently reported, including laminin $\beta 2$ and laminin $\alpha 5$ deficiencies and COL13A1 CMS, these are rare with only a few cases reported. 


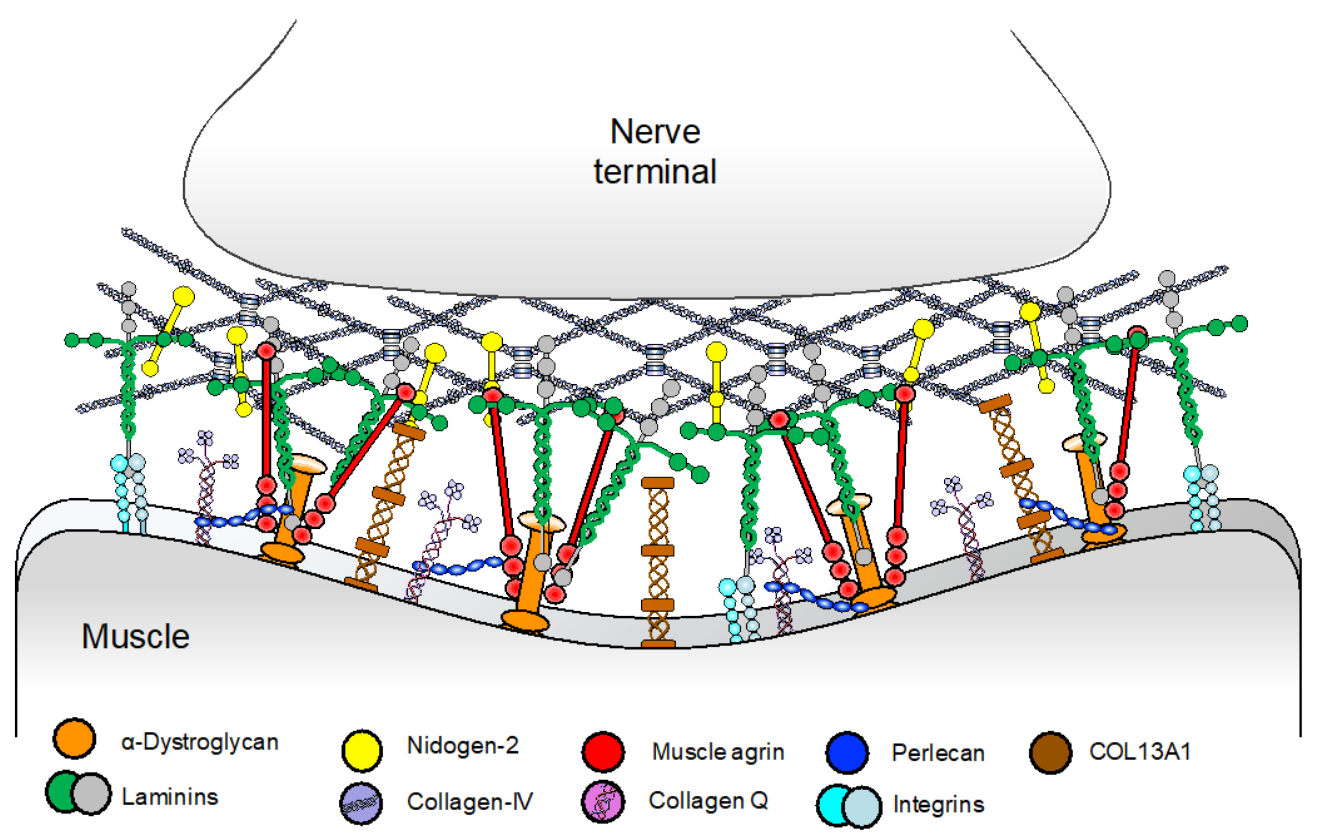

Figure 4. Schematic representation of the synaptic basal lamina and its main components. Laminins are heterotrimeric proteins of high molecular weight formed by the incorporation of $\alpha, \beta$, and $\gamma$ chains. Laminins self-assemble, but also interact with integrins and $\alpha$-dystroglycan [41]. Collagen IV, which is the most abundant protein at the basal lamina, self-assembles into dimers and hexamers thanks to its globular domains [41]. Nidogen-2 are non-collagenous glycoproteins responsible for linking collagen IV and laminin networks [42,43]. Additional collagens include COL13A1 [44] and COLQ, a collagen like tail responsible for anchoring AChE to the synaptic cleft. Muscle agrin binds to the basal lamina via laminin [45] and $\alpha$-dystroglycan [46], and this is important for maintenance of the NMJ [47]. This differs from the role of neuronal agrin as a key organiser of the postsynaptic apparatus via the AChR clustering pathway [48]. Perlecan, another synaptic heparan sulphate proteoglycan is linked to both ColQ [49] and $\alpha$-dystroglycan [50].

\section{1. $C O L Q$}

COLQ encodes the collagen-like tail subunit of asymmetric acetylcholinesterase (AChE), which anchors AChE to the basal lamina. Mutations in COLQ cause endplate AChE deficiency [51]. It is likely that neuromuscular transmission in COLQ CMS is impaired through different mechanisms. First, the prolonged time of $\mathrm{ACh}$ at the synaptic cleft produce desensitization of $\mathrm{AChRs}$ and secondary endplate myopathy with loss of AChRs due to sarcoplasmic $\mathrm{Ca}^{2+}$ overload [51]. Second, if COLQ mutations alter the interaction of ColQ with MuSK or perlecan, this could impact postsynaptic differentiation $[52,53]$. COLQ mutations have been reported in all domains of the protein with no phenotype-genotype correlation [54]. The classic phenotype is that of neonatal or early onset severe disease with ptosis, ophthalmoparesis, generalised weakness, respiratory difficulties, and progressive course [51]. Additional phenotypes include early onset disease with a mild course, and cases reminiscent of DOK7 CMS [54]. Repetitive CMAP from a single nerve stimulus can be seen due to prolonged endplate currents outlasting the refractory period of the muscle fibre [55]. Pyridostigmine and 3,4-DAP are contraindicated but some patients do respond to $\beta 2$-adrenergic agonists [56].

\subsection{COL13A1}

COL13A1 encodes the $\alpha$ chain of a non-fibrillar collagen, which has shown in vitro binding with other extracellular matrix proteins such as integrin $\alpha 1 \beta 1$ [57], nidogen, and perlecan [58]. Studies in animal models lacking COL13A1 identified abnormal maturation of the neuromuscular 
junction [44]. COL13A1 mutations have been reported in two unrelated families with CMS [59]. Onset of symptoms was at birth with breathing and feeding difficulties. Bilateral ptosis was present and eye movements were normal. The analysis of the muscle biopsy in the individual carrying the c.1171delG loss-of function mutation showed loss of COL13A1 expression at the muscle endplate. Functional analysis demonstrated a deleterious effect on AChR clustering in vitro. Treatment with 3,4-DAP and salbutamol was beneficial. The second family carried the homozygous splice site mutation c.523-1delG (p.Leu392fs*71), which is predicted to lead to premature termination (p.Gly175Vfs*20). Overall, these findings draw attention to the role of extracellular matrix proteins for the formation and maintenance of the NMJ. The beneficial effect of salbutamol would be consistent with COL13A1 mutations affecting AChR clustering and maturation of postsynaptic structures. The positive effect of 3,4-DAP is supported by the presynaptic abnormalities seen in the Col13a1 $1^{-/-}$mouse model such as abnormal clustering of synaptic vesicles in the motor nerve terminal.

\subsection{Laminin $\beta 2$ and Laminin $\alpha 5$ Deficiencies}

A single CMS case of laminin $\beta 2$ deficiency due to heteroallelic frameshift mutations in LAMB2 has been reported to date [60]. The neuromuscular phenotype was characterised by neonatal onset with breathing difficulties, ptosis, ophthalmoplegia, and profound proximal weakness. Cholinesterase inhibitors were deleterious in this single case. Additional features included congenital nephrosis and distinct eye abnormalities with microcoria (Pierson syndrome) [61] in keeping with Laminin $\beta 2$ being an important component of the glomerular basement membrane and intraocular muscles.

Homozygous missense mutations in LAMA5, encoding laminin $\alpha 5$, have been reported in a neonatal onset CMS combining myopia, facial tics, and abnormal neuromuscular transmission [62]. The endplates study found normal postsynaptic membrane but small nerve terminals. Neurophysiology showed abnormalities in keeping with a LEMS-like presynaptic defect. There was a positive response to treatment with pyridostigmine and 3,4-diaminopyridine.

\section{Postsynapatic Syndromes}

\subsection{Primary AChR Deficiency}

The adult nicotinic AChR is a pentameric complex composed of four different transmembrane subunits ( $2 \alpha, \beta, \delta$, and $\varepsilon$-subunits) encoded by CHRNA1, CHRNB1, CHRND, and CHRNE, respectively (Figure 5A). Primary AChR deficiency is characterised by reduced AChR numbers (10 to $30 \%$ of normal values) and integrity of the postsynaptic folding [63]. This CMS subtype is mainly caused by CHRNE mutations (Figure 5B) and accounts for approximately $30 \%$ of total CMS in the UK. These are found along the entire gene including the promoter region [64] and result in protein truncation, loss of essential residues (glycosylation sites, Cys-loop) for AChR assembly or function [65], or severely reduced levels of subunit mRNA expression. It is believed that incorporation of the foetal AChR $\gamma$-subunit into the AChR pentamer enables subjects with null $\varepsilon$-subunits alleles to survive [66]. The phenotypic spectrum of patients with primary AChR-deficiency is wide from mild to severe disease [64]. Most patients have a marked limitation of ocular movements, which is useful to guide genetic screening. Treatment with cholinesterase inhibitors and 3,4-DAP is beneficial, although the long-term response in severe cases is often incomplete [67]. Some patients may have dramatic responses to the addition of $\beta 2$-adrenergic agonists [68]. 

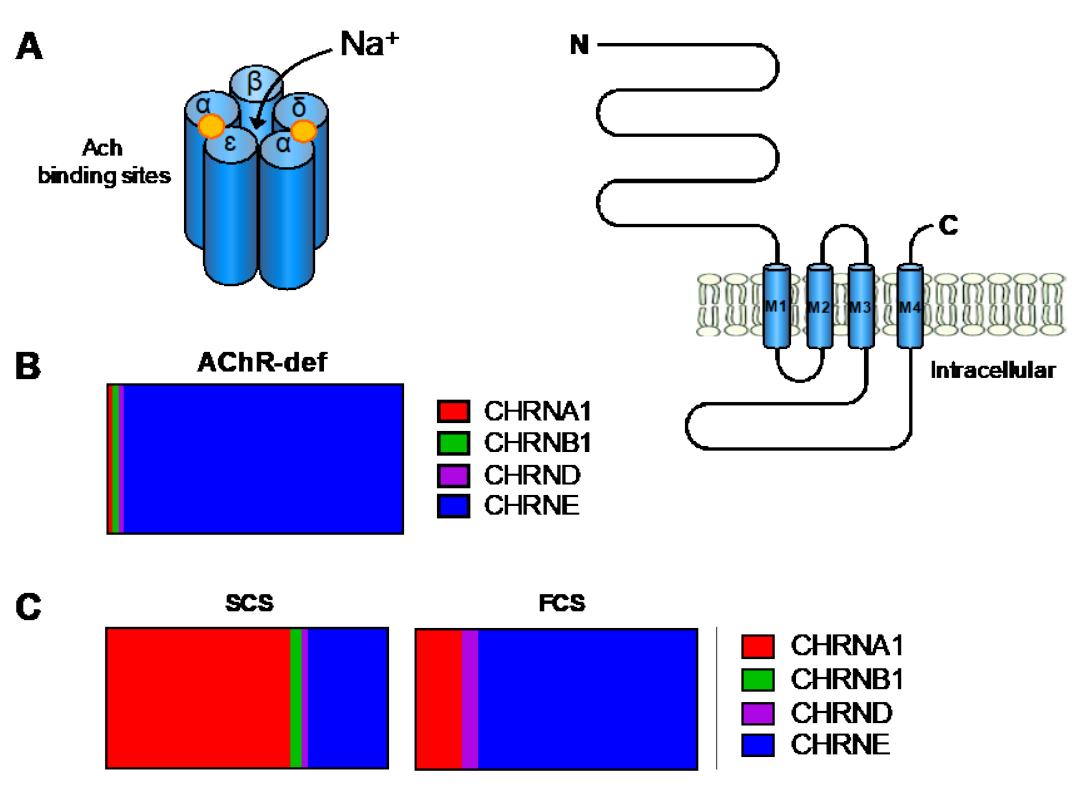

Figure 5. The adult AChR and the genetics of AChR-deficiency and kinetics abnormalities of the AChR. (A) The AChR is made up of five subunits organised around a central pore. Each subunit is composed of an extracellular domain, four transmembrane domains (M1-M4), and a large cytoplasmic loop that links M3 and M4; (B,C) Relative proportion of genetic defects in patients with AChR deficiency and kinetic abnormalities of the AChR within the Oxford CMS cohort. AChR deficiency is mainly caused by mutations in CHRNE encoding the $\varepsilon$-subunit of the AChR. SCS is often caused by mutations in CHRNA1 encoding the AChR $\alpha$-subunit, while FCS is most commonly due to mutations in CHRNE.

\subsection{Kinetic Abnormalities of the AChR (with or without AChR Deficiency)}

Mutations in any of the four AChR adult subunits can also alter ion channel function leading to prolonged (slow channel syndrome, SCS) or abbreviated openings (fast channel syndrome, FCS). However, mutations in CHRNA1 and CHRNE are the most frequent (Figure 5C). This group represents approximately $15 \%$ of total CMS cases in the UK.

SCS was the only CMS with autosomal dominant inheritance until the recent descriptions of CMS due to SNAP25 and SYT2 mutations. The underlying pathogenic mechanism is prolonged AChR opening, which causes desensitisation of AChRs, depolarisation block, and secondary endplate myopathy due to cationic overload [69] and focal activation of caspases [70]. The age of symptom onset in SCS is very variable, from birth to the fifth decade, and patients are in general not as severely affected as other subtypes. Ptosis and ophthalmoparesis can be present but to a lesser degree than in primary AChR deficiency. There is often selective impairment of cervical and distal upper limb muscles. Treatment is with AChR open channel blockers such as fluoxetine or quinidine [71]. Drugs increasing ACh levels can be deleterious.

FCS result in brief channel openings with secondary reduced postsynaptic depolarisation and failure to trigger muscle action potentials [72]. Many FCS are characterised by severe weakness from birth, ptosis, ophthalmoplegia, and life-threatening respiratory crises that may be fatal [73]. FCS is rare because, in order to define the clinical phenotype, the FCS mutation needs to be homozygous or in compound heterozygosis with a null or low expressor mutation. The $\varepsilon \mathrm{P} 121 \mathrm{~L}$ variant, which is critical for binding of acetylcholine [74], is the most common FCS mutation in the UK [73]. Pyridostigmine and 3,4-DAP are beneficial, although the effect may decrease with time.

\subsection{Defects within the AChR-Clustering Pathway}

The AChR clustering signaling pathway is essential for the formation and maintenance of the NMJ [75] (Figure 6). Upon release of agrin by the nerve terminal, agrin binds to LRP4 at 
the postsynaptic membrane resulting in MuSK dimerisation and activation [76]. This leads to the recruitment of DOK7, a muscle-specific cytoplasmic adaptor of MuSK that further stimulates MuSK kinase activity propagating the signal downstream through mechanisms still not elucidated. It results in the phosphorylation of the AChR $\beta$-subunit, which promotes binding of the cytoplasmic anchoring protein rapsyn and final stabilisation of innervated AChR clusters [77]. Additional players (although their role is still poorly understood) include CrK/CrKL [78] and possibly Dishevelled [79], a scaffold protein involved in Wnt signaling pathways [80].

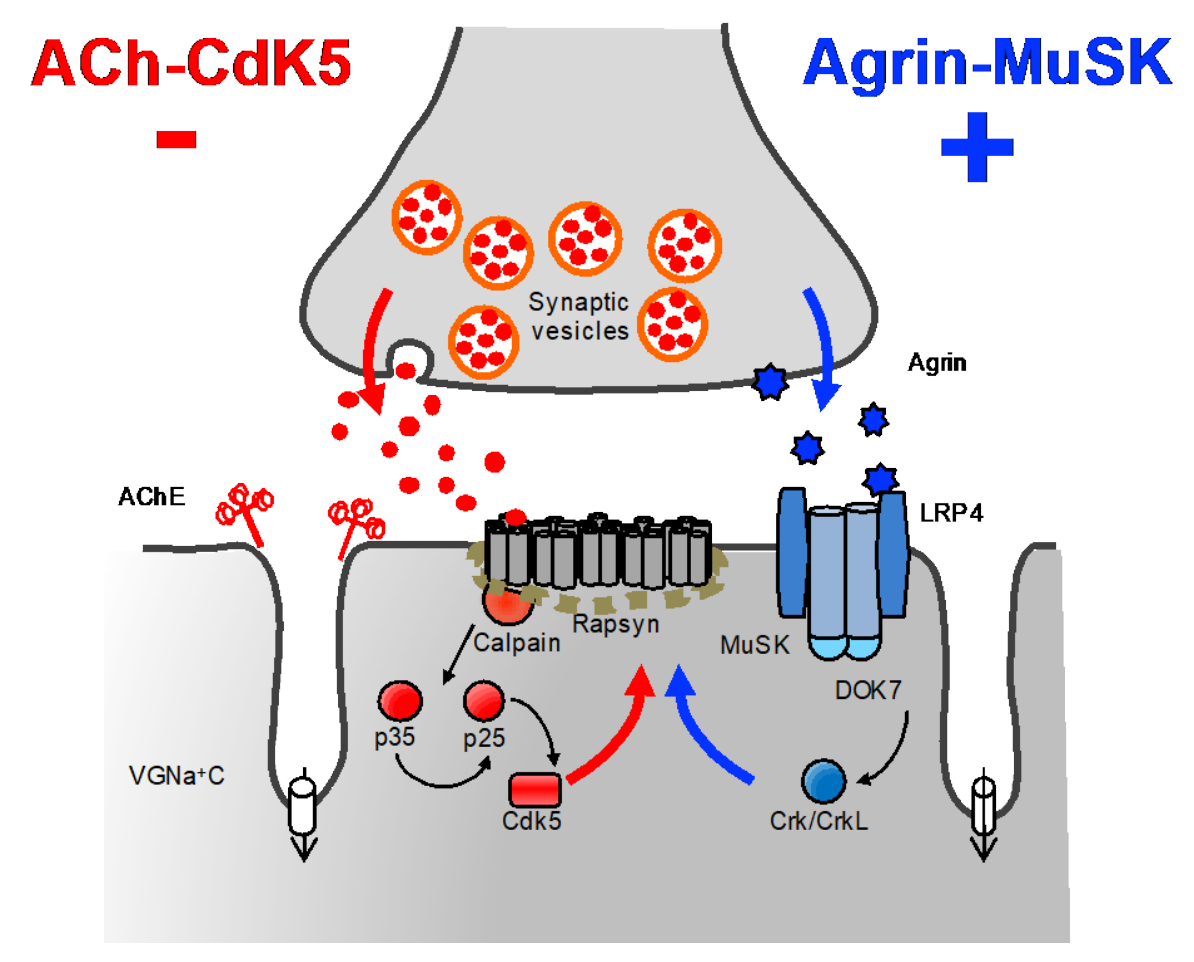

Figure 6. The agrin-induced AChR clustering and ACh-CdK5 dispersal pathways. The AChR clustering pathway is shown blue and the dispersal pathway in red. Main molecules with a role in synapse formation and maintenance are represented although additional, still unknown, positive and negative factors are very likely to be involved. CMS patients harboring mutations within the AChR clustering pathway (excluding RAPSN) present common clinical features such as relative sparing of eye muscles, predominant limb girdle weakness, worsening of symptoms with drugs increasing ACh levels, and improvement on long-term therapy with $\beta 2$-adrenergic agonists. DOK7 CMS represents the most frequent subtype in this category with other syndromes being rather infrequent.

By contrast to the AChR clustering pathway, a negative signal disperses aneural AChR clusters not stabilised by agrin signaling (Figure 6). This pathway is thought to be driven by ACh through a cyclin-dependent kinase 5 (Cdk5) mechanism [81] linked to the interaction of rapsyn and the calcium-dependent protease calpain [82]. Calpain promotes the cleavage of p35 to p25, a potent activator of Cdk5 [83]. Rapsyn is believed to stabilise AChR clusters by suppressing calpain activity [82].

\subsubsection{AGRN}

AGRN mutations account for a rare CMS subtype with only four reports published to date. The phenotypic spectrum is variable from very severe disease with respiratory failure [84] to a mild CMS with running difficulties [85], limb-girdle weakness [86], or dropped head presentation [87]. Overall, there is no clear phenotype-genotype correlation, including a recent report of five patients from three different kinships with a similar phenotype comprising CMS with distal muscle weakness 
and atrophy [88]. Of note, extraocular muscles were usually spared or modestly affected in keeping with other CMS impairing the AChR clustering pathway. Most patients were unresponsive to pyridostigmine and 3,4-DAP, but some had a clear benefit on $\beta 2$-adrenergic agonists [88].

\subsubsection{LRP4}

The nerve terminal releases agrin that binds to the low-density lipoprotein receptor-related protein 4 (LRP4) forming a ternary complex with MuSK that triggers MuSK phosphorylation [76,89]. CMS due to LRP4 mutations is extremely rare with only three patients from two different kinships reported to date $[90,91]$. The clinical features of the few patients reported were variable with one case of early onset severe myasthenia and two milder cases with onset in childhood after normal or slightly delayed motor milestones. In a similar fashion to DOK7 CMS, patients improved on $\beta 2$-adrenergic agonists while pyridostigmine worsened muscle weakness. All patients harboured missense mutations located at the third propeller domain of LRP4 that prevent MuSK activation. Mutations in other domains of LRP4 may cause Cenani-Lenz syndrome.

\subsubsection{MuSK}

MUSK encodes the muscle specific kinase (MuSK), a key element of the agrin signalling pathway [92]. MuSK is composed of three IgG-like domains, a frizzled domain, and a kinase domain. MUSK mutations represent a very rare cause of CMS with only few cases reported [93-96]. However, given the role of MuSK and DOK7 in the same pathway, it is noteworthy that the clinical features and treatment response are similar in both conditions, with predominant limb girdle weakness, sparing of eye muscles, and worsening with cholinesterase inhibitors. A recent report suggests an increased likelihood of a severe, respiratory phenotype with null alleles, while late onset CMS may be associated with missense variants affecting the kinase domain (excluding the catalytic site) [96].

\subsubsection{DOK7}

DOK7 is a muscle-specific cytoplasmic adaptor protein of MuSK, which is essential for postsynaptic specialization of the NMJ [97]. Mutations in DOK7 underlie a NMJ synaptopathy [98], which accounts for approximately $15-20 \%$ of total CMS cases in the UK. The spectrum of DOK7 mutations is wide although most patients have at least one mutation within the C-terminus, with c.1124_1127dupTGCC present in approximately 65\% of the cases [99]. Although patients occasionally may present in adulthood, the classic phenotype is characterised by onset of symptoms in childhood after normal motor milestones, with progressive limb-girdle weakness and walking difficulties [98]. Patients have ptosis but eye movements are typically normal. The clinical spectrum varies from mild limb-girdle weakness to generalised and severe weakness. There is no clear genotype-phenotype correlation [100]. Patients can improve dramatically on $\beta 2$-adrenergic agonists in the course of months [101].

\subsection{Rapsyn Deficiency}

RAPSN encodes the $43 \mathrm{kDa}$ receptor-associated scaffold protein of the synapse [102], which is essential for stabilisation of AChR clusters at the muscle endplate $[103,104]$. Rapsyn is enriched at postsynaptic membranes and acts as a linker between the AChRs and the cytoskeleton via the dystrophin-associated glycoprotein complex [105]. The detailed organisation of the AChRs-rapsyn network is not fully understood since the crystallographic structure has not been solved [106].

Rapsyn CMS is characterised by deficiency of AChRs at the postsynaptic membrane and poor development of postjunctional folds [107]. RAPSN mutations have been reported across the entire length of the gene although most patients are either homozygous for p.N88K mutation or heteroallelic for p.N88K and a second mutation [108]. The major effect of p.N88K is to reduce the stability of AChR clusters [108]. Most patients with RAPSN mutations present at birth or early in life with generalised hypotonia, respiratory weakness, and feeding difficulties $[109,110]$. Mild arthrogryposis, 
facial dysmorphism, ptosis, and strabismus are usually present but ophthalmoplegia is rare. Life-threatening respiratory crises are frequent during infancy and early childhood. Additional phenotypes include lethal foetal akinesia [111] and a late onset milder disease [109]. Treatment with pyridostigmine and 3,4-DAP is beneficial. Most patients improve with age and have a good long-term prognosis [112].

\section{CMS Due to Abnormal Glycosylation}

The $N$-linked glycosylation pathway is a ubiquitous process in eukaryote cells defined by the sequential attachment of sugar moieties to the lipid dolichol, which is then transferred to an asparagine residue in a protein (Figure 7). Mutations in components within this pathway produce a spectrum of severe multisystemic disorders known as congenital disorders of glycosylation [113-115]. In addition, NGS has aided the discovery of an unexpected relationship between glycosylation defects in the early stages of the $\mathrm{N}$-glycosylation pathway and CMS [116-118]. The reasons why, in certain cases, defects in a ubiquitous process result in dysfunction largely restricted to the NMJ is unclear.

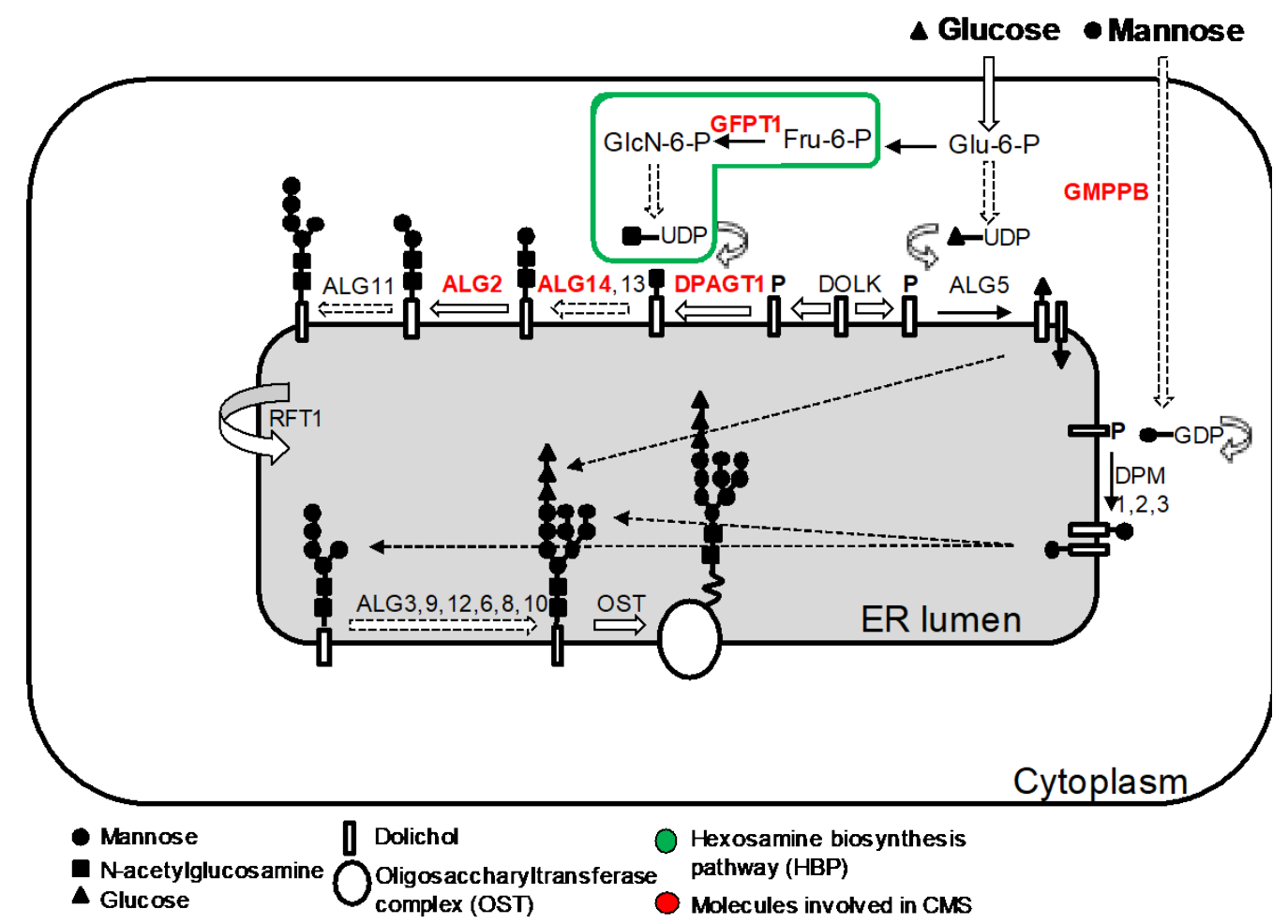

Figure 7. Simplified representation of the $N$-glycosylation pathway of proteins and the molecules involved in CMS. The N-linked glycosylation of proteins takes place in the ER. It starts with the assembly of the core glycan ( $N$-acetylglucosamine, glucose and mannose) on the lipid dolichol. A series of cytosolic glycosyltransferases proceed to dolichol glycosylation on the cytoplasmic face of the ER: GFPT1 synthesizes UDP-GlcNAc (Uridine diphosphate $N$-acetylglucosamine); DPAGT1 and the ALG13/14 complex are involved in adding the first and second $N$-acetylglucosamine to dolichol. Additional sugar residues are added by ALG2 and other enzymes until the resulting product is flipped into the ER lumen by RFT1. Inside the ER lumen, sugar moieties are incorporated until the glycan is transferred to asparagine residues of nascent proteins by the multimeric oligosaccharyl transferase complex (OST) that subsequently will be modified inside the ER and Golgi. DOLK, dolichol kinase; DPM, dolichol-phosphate mannose synthase; Fru-6-P, fructose-6-phosphate; GlcN-6-P, glucosamine-6-phosphate; Glu-6-P, glucose-6-phosphate; GMPPB, GDP-mannose pyrophosphrylase B. 
Glycosylation of AChR subunits is required for the correct assembly of AChR pentamers and for efficient export to the cell surface [119] and thus abnormal glycosylation results in reduced AChRs at the muscle endplates, which is most likely the primary mechanisms leading to impaired neuromuscular transmission [120].

These patients constitute a distinctive clinical group where muscle weakness is often confined to the limb girdles, and classic myasthenic manifestations-such as ptosis, ophthalmoplegia, or facial weakness-are not present. In relation to this, RNS and SFEMG of facial muscles are often normal causing diagnostic difficulties and thus neurophysiology should also be performed in proximal muscles. Concomitant myopathy is often present, which makes it a progressive condition over time. The myasthenic component can be treated with a combination of pyridostigmine, 3,4-DAP and salbutamol. Intellectual disability is also seen in some cases. The description of this novel group of disorders points that CMS should be part of the differential diagnosis of limb girdle muscle weakness.

\subsection{GFPT1}

GFPT1 encodes glutamine-fructose-6-phosphate transaminase-1 (GFAT1). This enzyme catalyses the first step in the biosynthesis of UDP- $N$-acetylglucosamine, an essential substrate for $N$ - and O-glycosylation of proteins [121]. GFPT1 knock-down in zebrafish embryos confirmed that GFPT1 is required for NMJ formation [117]. Mutations in GFPT1 have been identified in more than 50 patients to date causing an autosomal recessive limb-girdle CMS [117,122-124]. The clinical presentation is usually with proximal muscle weakness and sparing of ocular and facial muscles. Clinical onset of symptoms is variable from early childhood to the second and third decades. If present, modestly elevated serum creatine kinase (CK) levels and additional myopathic changes on needle EMG suggest a concomitant myopathy [123]. Tubular aggregates (TA) are commonly found on muscle biopsy. The expression of $\alpha$-dystroglycan is preserved. Treatment with AChE inhibitors and 3,4-DAP is beneficial [125].

\subsection{DPAGT1}

DPAGT1 encodes the enzyme dolichyl-phosphate- $N$-acetylglucosamine-phophotranferase- 1 that catalyses the first step in the dolichol oligosaccharide pathway for glycoprotein biosynthesis [126]. CMS due to DPAGT1 mutations has been reported in 12 patients [127-129]. Presentation is during infancy or childhood with prominent limb-girdle weakness and minimal craniobulbar manifestations [130]. The spectrum of severity is variable but life-threatening crisis are rare [127]. A concomitant myopathy is present with or without tubular aggregates. Cognitive manifestations can vary from none to mild learning difficulties or major intellectual disability [128]. Endplate studies have shown pre- and postsynaptic abnormalities with reduction of postsynaptic folding, small nerve terminals, and reduced $\alpha$-bungarotoxin labelling. Therapy with pyridostigmine and 3,4-DAP is usually beneficial. Of note, $\beta 2$-adrenergic agonists had a clear benefit in two patients $[128,130]$.

\subsection{ALG2 and ALG14}

ALG14 is thought to form, together with ALG13 and DPAGT1, a functional multienzyme complex involved in the initial steps of $N$-linked protein glycosylation [131]. ALG2 encodes alpha-1,3-mannosyltransferase that catalyses the second and third mannosylation steps for the elongation of the carbohydrate chain linked to dolichol [132]. Both ALG2 and ALG14 are concentrated at motor endplates and RNA silencing of ALG14 results in reduced cell-surface expression of AChRs in heterologous cells [118]. CMS due to mutations in ALG2 and ALG14 is very rare with only nine patients from three different kinships reported to date $[118,133]$. Clinical features are similar to those described in patients with GFPT1 and DPAGT1 CMS.

\section{4. $G M P P B$}

GMPPB encodes GDP-mannose pyrophosphorylase B that catalyses the conversion of mannose-1-phosphate and GTP to GDP-mannose. GMPPB contributes to both the O-mannosylation 
and $\mathrm{N}$-glycosylation pathways. Mutations within the $\mathrm{O}$-mannosylation pathway were originally identified in patients with dystroglycanopathies, a form of muscular dystrophy characterised by reduced $\alpha$-dystroglycan glycosylation [134]. More recently, it was shown that mutations in GMPPB can also cause CMS and bridge myasthenic disorders with dystroglycanopathies [135]. Patients with GMPPB CMS have prominent limb-girdle weakness with minimal or absent craniobulbar manifestations [136]. Presentation is often delayed beyond infancy with proximal muscle weakness although patients often recall poor performance in sports during childhood. Muscle biopsy typically shows dystrophic features and reduced $\alpha$-dystroglycan glycosylation. Myopathic changes can be present on muscle MRI and serum CK is significantly increased compared to other CMS subtypes. Patients are responsive to acetylcholinesterase inhibitors alone or combined with 3,4-diaminopyridine and/or salbutamol.

\section{Treatment}

The CMS treatment strategy used in the Oxford CMS Service is provided for the most common CMS subtypes (Figure 8). As shown in the figure, genetic diagnosis is crucial to provide adequate pharmacological treatment for every CMS subtype.

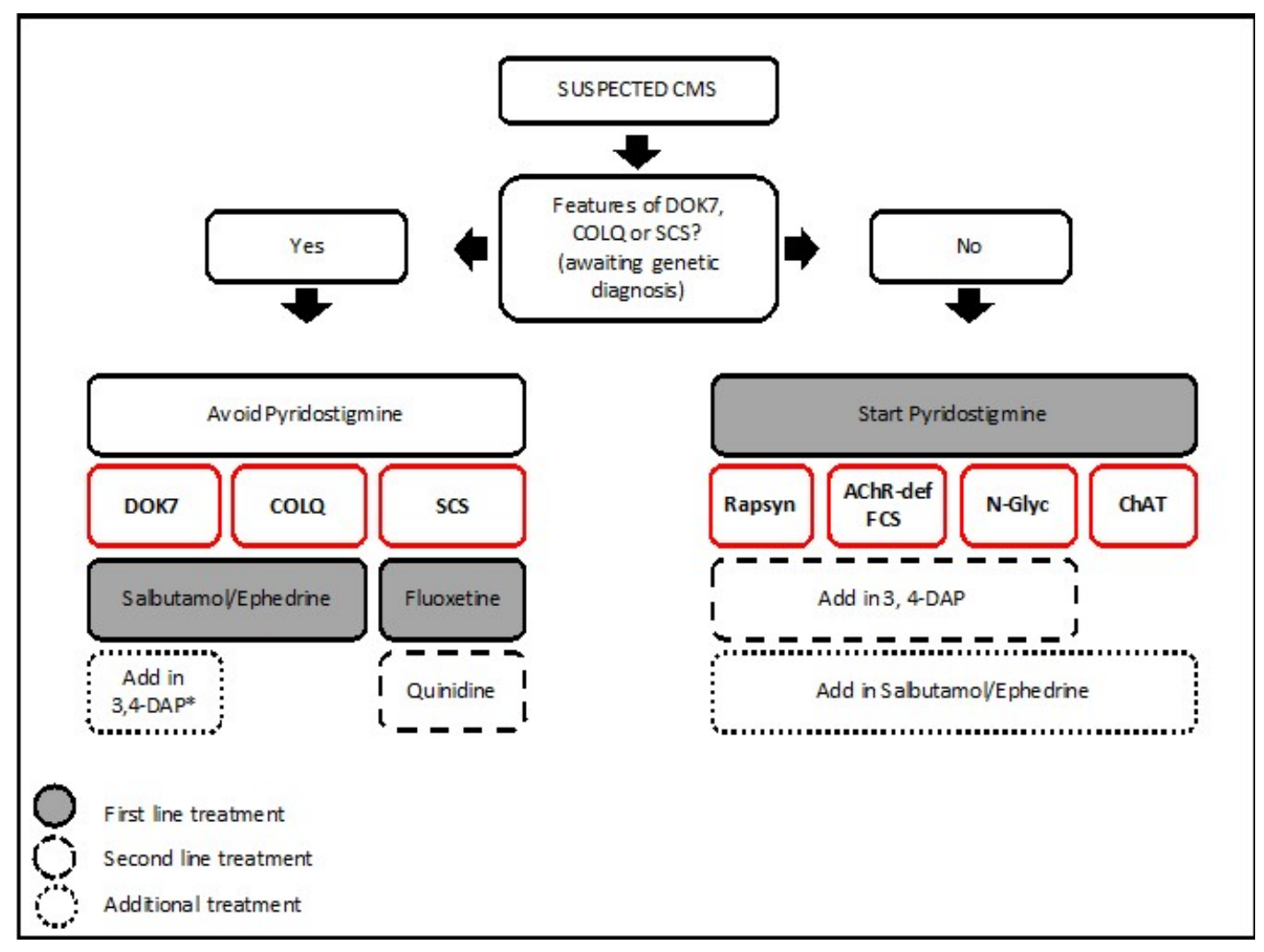

Figure 8. Treatment strategy at the Oxford CMS Service for most common CMS subtypes. Whenever features of DOK7 and other members of the AGRN-MUSK pathway, COLQ, or SCS are present, first-line treatment with pyridostigmine should be avoided until confirmation of genetic diagnosis. 3,4-DAP can be added in with caution in certain CMS subtypes (* use with caution) [137]. Combined therapy with $\beta 2$-adrenergic agonists may be tried on AChR deficiency, CMS due to glycosylation defects, FCS, and rapsyn CMS. In cases of SCS, quinidine may be used as an alternative to fluoxetine. FCS, Fast channel syndrome; N-glyc, N-glycosylation pathway; SCS, slow channel syndrome.

Classic treatments include acetylcholinesterase inhibitors (pyridostigmine-Mestinon ${ }^{\circledR}$ ) to inhibit acetylcholinesterase from breaking down acetylcholine [138]; 3,4-DIaminopyridine (3,4-DAP) that 
works by blocking presynaptic potassium channels and thus increases the action potential duration and acetylcholine release [139]; fluoxetine and quinide work as open channel blockers to restore synaptic currents in slow channel syndrome [140].

A number of studies have reported the remarkable benefit of therapy with $\beta 2$-adrenergic agonists such as salbutamol and ephedrine in DOK7 CMS [101,141,142]. The use of these drugs is increasingly being reported in other CMS subtypes such as AChR-deficiency [68], acetylcholinesterase deficiency [54,143], and CMS due to abnormal glycosylation $[128,130]$. The molecular mechanism for salbutamol and ephedrine at the NMJ is unknown. In patients with mutations in the AGRN-MUSK-DOK7 pathway, there is a slow but progressive and marked response starting within weeks and increasing in effect before stabilising at 6-24 months [101]. In patients with AChR-deficiency on pyridostigmine, the effect on muscle strength and fatiguabilty seems already significant within the first two weeks of starting treatment, although the improvement can continue until the first 6-12 months [68]. These observations suggest that the benefit of $\beta 2$-adrenergic agonists do not derive from short-term effect on neuromuscular transmission, but from a long-term effect probably related to increased structural stability or remodeling of the muscle endplates. The development of more specific $\beta 2$-adrenergic receptor agonists would be of interest to maximize the benefits of pharmacological treatment while avoiding generalized side effects derived from adrenergic stimulation.

Acknowledgments: No specific funding has been received for this study. We gratefully acknowledge the UK NHS National Highly Specialised Service for funding to the Diagnostic and Advisory service for CMS in Oxford. D.B. holds MRC Programme Grant MR/M006824/1.

Conflicts of Interest: The authors declare no conflict of interest.

\section{References}

1. Palace, J.; Beeson, D. The congenital myasthenic syndromes. J. Neuroimmunol. 2008, 201-202, 2-5. [CrossRef] [PubMed]

2. Parr, J.R.; Andrew, M.J.; Finnis, M.; Beeson, D.; Vincent, A.; Jayawant, S. How common is childhood myasthenia? The UK incidence and prevalence of autoimmune and congenital myasthenia. Arch. Dis. Child. 2014, 5-9. [CrossRef] [PubMed]

3. Zhang, B.; Shen, C.; Bealmear, B.; Ragheb, S.; Xiong, W.-C.; Lewis, R.A.; Lisak, R.P.; Mei, L. Autoantibodies to agrin in myasthenia gravis patients. PLoS ONE 2014, 9, e91816. [CrossRef] [PubMed]

4. Pevzner, A.; Schoser, B.; Peters, K.; Cosma, N.-C.; Karakatsani, A.; Schalke, B.; Melms, A.; Kröger, S. Anti-LRP4 autoantibodies in AChR- and MuSK-antibody-negative myasthenia gravis. J. Neurol. 2012, 259, 427-435. [CrossRef] [PubMed]

5. Leite, M.I.; Jacob, S.; Viegas, S.; Cossins, J.; Clover, L.; Morgan, B.P.; Beeson, D.; Willcox, N.; Vincent, A. IgG1 antibodies to acetylcholine receptors in "seronegative" myasthenia gravis. Brain 2008, 1940-1952. [CrossRef] [PubMed]

6. Rodríguez Cruz, P.M.; Sewry, C.; Beeson, D.; Jayawant, S.; Squier, W.; McWilliam, R.; Palace, J. Congenital myopathies with secondary neuromuscular transmission defects; A case report and review of the literature. Neuromuscul. Disord. 2014, 24, 1103-1110. [CrossRef] [PubMed]

7. Jaeken, J.; Martens, K.; Francois, I.; Eyskens, F.; Lecointre, C.; Derua, R.; Meulemans, S.; Slootstra, J.W.; Waelkens, E.; de Zegher, F.; et al. Deletion of PREPL, a gene encoding a putative serine oligopeptidase, in patients with hypotonia-cystinuria syndrome. Am. J. Hum. Genet. 2006, 78, 38-51. [CrossRef] [PubMed]

8. Lai, Y.; Choi, U.B.; Leitz, J.; Brose, N.; Rhee, J.; Brunger, A.T.; Lai, Y.; Choi, U.B.; Leitz, J.; Rhee, H.J.; et al. Molecular Mechanisms of Synaptic Vesicle Priming Article Molecular Mechanisms of Synaptic Vesicle Priming by Munc13 and Munc18. Neuron 2017, 95, 591-607. [CrossRef] [PubMed]

9. Ma, C.; Su, L.; Seven, A.B.; Xu, Y.; Rizo, J. Reconstitution of the Vital Functions of Munc18 and Munc13 in Neurotransmitter Release. Science 2013, 339, 421-426. [CrossRef] [PubMed]

10. Hartman, M.A.; Finan, D.; Sivaramakrishnan, S.; Spudich, J.A. Principles of Unconventional Myosin Function and Targeting. Annu. Rev. Cell Dev. Biol. 2011, 27, 133-155. [CrossRef] [PubMed]

11. Bridgman, P.C. Myosin Motor Proteins in the Cell Biology of Axons and Other Neuronal Compartments. In Cell Biology of the Axon; Koenig, E., Ed.; Springer: Berlin/Heidelberg, Germany, 2009; pp. 91-105. 
12. O'Connor, E.; Töpf, A.; Müller, J.S.; Cox, D.; Evangelista, T.; Colomer, J.; Abicht, A.; Senderek, J.; Hasselmann, O.; Yaramis, A.; et al. Identification of mutations in the MYO9A gene in patients with congenital myasthenic syndrome. Brain 2016, 1-11. [CrossRef]

13. Shen, X.-M.; Crawford, T.O.; Brengman, J.; Acsadi, G.; Iannaconne, S.; Karaca, E.; Khoury, C.; Mah, J.K.; Edvardson, S.; Bajzer, Z.; et al. Functional consequences and structural interpretation of mutations of human choline acetyltransferase. Hum. Mutat. 2011, 32, 1259-1267. [CrossRef] [PubMed]

14. Maselli, R.A.; Chen, D.; Delores, M.; Bowe, C.; Fenton, G.; Wollmann, R.L. Choline acetyltransferase mutations in myasthenic syndrome due to deficient acetylcholine resynthesis. Muscle Nerve 2003, 27, 180-187. [CrossRef] [PubMed]

15. Ohno, K.; Tsujino, A.; Brengman, J.M.; Harper, C.M.; Bajzer, Z.; Udd, B.; Beyring, R.; Robb, S.; Kirkham, F.J.; Engel, A.G. Choline acetyltransferase mutations cause myasthenic syndrome associated with episodic apnea in humans. Proc. Natl. Acad. Sci. USA 2001, 98, 2017-2022. [CrossRef] [PubMed]

16. Schara, U.; Christen, H.-J.; Durmus, H.; Hietala, M.; Krabetz, K.; Rodolico, C.; Schreiber, G.; Topaloglu, H.; Talim, B.; Voss, W.; et al. Long-term follow-up in patients with congenital myasthenic syndrome due to CHAT mutations. Eur. J. Paediatr. Neurol. 2010, 14, 326-333. [CrossRef] [PubMed]

17. Lone, A.M.; Nolte, W.M.; Tinoco, A.D.; Saghatelian, A. Peptidomics of the prolyl peptidases. AAPS J. 2010, 12, 483-491. [CrossRef] [PubMed]

18. Martens, K.; Derua, R.; Meulemans, S.; Waelkens, E.; Jaeken, J.; Matthijs, G.; Creemers, J.W.M. PREPL: A putative novel oligopeptidase propelled into the limelight. Biol. Chem. 2006, 387, 879-883. [CrossRef] [PubMed]

19. Kim, M.-H.; Hersh, L.B. The vesicular acetylcholine transporter interacts with clathrin-associated adaptor complexes AP-1 and AP-2. J. Biol. Chem. 2004, 279, 12580-12587. [CrossRef] [PubMed]

20. Régal, L.; Shen, X.-M.; Selcen, D.; Verhille, C.; Meulemans, S.; Creemers, J.W.M.; Engel, A.G. PREPL deficiency with or without cystinuria causes a novel myasthenic syndrome. Neurology 2014. [CrossRef] [PubMed]

21. Okuda, T.; Haga, T.; Kanai, Y.; Endou, H.; Ishihara, T. Identification and characterization of the high-affinity choline transporter. Nat. Neurosci. 2000, 3, 120-125. [CrossRef] [PubMed]

22. Bauché, S.; O’Regan, S.; Azuma, Y.; Laffargue, F.; McMacken, G.; Sternberg, D.; Brochier, G.; Buon, C.; Bouzidi, N.; Topf, A.; et al. Impaired Presynaptic High-Affinity Choline Transporter Causes a Congenital Myasthenic Syndrome with Episodic Apnea. Am. J. Hum. Genet. 2016, 99, 753-761. [CrossRef] [PubMed]

23. Arvidsson, U.L.F.; Riedl, M.; Elde, R.; Meister, B. Vesicular acetylcholine transporter (VAChT) protein: A novel and unique marker for cholinergic neurons in the central and peripheral nervous systems. J. Comp. Neurol. 1997, 467, 454-467. [CrossRef]

24. O'Grady, G.L.; Verschuuren, C.; Yuen, M.; Webster, R.; Menezes, M.; Fock, J.M.; Pride, N.; Best, H.A.; Benavides Damm, T.; Turner, C.; et al. Variants in SLC18A3, vesicular acetylcholine transporter, cause congenital myasthenic syndrome. Neurology 2016, 87, 1442-1448. [CrossRef] [PubMed]

25. Aran, A.; Renbaum, P.; Oliphant, S.; Weinberg, A.; Zeligson, S.; Lee, M.K.; Samson, A.O.; Parsons, S.M.; King, M. Vesicular acetylcholine transporter defect underlies devastating congenital myasthenia syndrome. Neurology 2017, 88, 1021-1028. [CrossRef] [PubMed]

26. Chen, Y.A.; Scheller, R.H.; Medical, H.H. Snare-mediated membrane fusion. Nature 2001, 2, $98-106$. [CrossRef] [PubMed]

27. Eaton, L.M.; Lambert, E.H. Electromyography and electric stimulation of nerves in diseases of motor unit; observations on myasthenic syndrome associated with malignant tumors. J. Am. Med. Assoc. 1957, 163, 1117-1124. [CrossRef] [PubMed]

28. Oyler, G.A.; Higgins, G.A.; Hart, R.A.; Battenberg, E.; Billingsley, M.; Bloom, F.E.; Wilson, M.C. The Identification of a Novel Synaptosomal-associated Protein, SNAP-25, Differentially Expressed by Neuronal Subpopulations. J. Cell Biol. 1989, 109, 3039-3052. [CrossRef] [PubMed]

29. Chapman, E.R.; An, S.; Barton, N.; Jahn, R. SNAP-25, a t-SNARE Which Binds to Both Syntaxin and Synaptobrevin via Domains That May Form Coiled Coils. J. Biol. Chem. 1994, 269, 27427-27432. [PubMed]

30. Shen, X.; Brengman, J.; Engel, A.G. Mutant SNAP25B causes myasthenia, cortical hyperexcitability, ataxia, and intellectual disability. Neurology 2014, 83, 2247-2255. [CrossRef] [PubMed]

31. Pang, Z.P.; Melicoff, E.; Padgett, D.; Liu, Y.; Teich, A.F.; Dickey, B.F.; Lin, W.; Adachi, R.; Su, T.C. Synaptotagmin-2 Is Essential for Survival and Contributes to $\mathrm{Ca}^{2+}$ Triggering of Neurotransmitter Release in Central and Neuromuscular Synapses. J. Neurosci. 2006, 26, 13493-13504. [CrossRef] [PubMed] 
32. Herrmann, D.N.; Horvath, R.; Sowden, J.E.; Gonzalez, M.; Gonzales, M.; Sanchez-Mejias, A.; Guan, Z.; Whittaker, R.G.; Almodovar, J.L.; Lane, M.; et al. Synaptotagmin 2 mutations cause an autosomal-dominant form of lambert-eaton myasthenic syndrome and nonprogressive motor neuropathy. Am. J. Hum. Genet. 2014, 95, 332-339. [CrossRef] [PubMed]

33. Whittaker, R.G.; Herrmann, D.N.; Bansagi, B.; Hasan, B.A.S.; Lofra, R.M.; Logigian, E.L.; Sowden, J.E.; Almodovar, J.L.; Littleton, J.T.; Zuchner, S.; et al. Electrophysiologic features of SYT2 mutations causing a treatable neuromuscular syndrome. Neurology 2015, 85, 1964-1971. [CrossRef] [PubMed]

34. Liu, Y.; Sugiura, Y.; Lin, W. The role of Synaptobrevin1/VAMP1 in $\mathrm{Ca}^{2+}$-triggered neurotransmitter release at the mouse neuromuscular junction. J. Physiol. 2011, 7, 1603-1618. [CrossRef] [PubMed]

35. Elferink, L.A.; Trimbles, W.S. Two Vesicle-associated Membrane Protein Genes Are Differentially Expressed in the Rat Central Nervous System. J. Biol. Chem. 1989, 264, 11061-11064. [PubMed]

36. Salpietro, V.; Lin, W.; Vedove, A.D.; Storbeck, M.; Liu, Y.; Efthymiou, S.; Manole, A.; Ye, Q.; Saggar, A.; Mcelreavey, K.; et al. Homozygous Mutations in VAMP1 cause a presynaptic congenital myasthenic syndrome. Ann. Neurol. 2017, 81, 597-603. [CrossRef] [PubMed]

37. Brose, N.; Hofmann, K.; Hata, Y.; Su, T.C. Mammalian Homologues of Caenorhabditis elegans unc-13 Gene Define Novel Family of C2-domain Proteins. J. Biol. Chem. 1995, 270, 25273-25280. [CrossRef] [PubMed]

38. Engel, A.G.; Selcen, D.; Shen, X.-M.; Milone, M.; Harper, C.M. Loss of MUNC13-1 function causes microcephaly, cortical hyperexcitability, and fatal myasthenia. Neurol. Genet. 2016, 5, e105. [CrossRef] [PubMed]

39. Sanes, J.R. The Basement Membrane/Basal Lamina of Skeletal Muscle. J. Biol. Chem. 2003, 287, 12601-12604. [CrossRef] [PubMed]

40. Shi, L.; Fu, A.K.Y.; Ip, N.Y. Molecular mechanisms underlying maturation and maintenance of the vertebrate neuromuscular junction. Trends Neurosci. 2012, 35, 441-453. [CrossRef] [PubMed]

41. Mouw, J.K.; Ou, G.; Weaver, V.M.; Regeneration, T.; Francisco, S.; Francisco, S.; Francisco, S.; Sciences, T.; Francisco, S.; Francisco, S.; et al. Extracellular matrix assembly: A multiscale deconstruction. Nat. Rev. Mol. Cell Biol. 2014, 15, 771-785. [CrossRef] [PubMed]

42. Mokkapati, S.; Nischt, R.; Smyth, N.; Ho, M.S.P.; Bo, K. Nidogens-Extracellular Matrix Linker Molecules. Microsc. Res. Tech. 2008, 395, 387-395. [CrossRef]

43. Fox, M.A.; Ho, M.S.P.; Smyth, N.; Sanes, J.R. A synaptic nidogen: Developmental regulation and role of nidogen-2 at the neuromuscular junction. Neural Dev. 2008, 17, 1-17. [CrossRef] [PubMed]

44. Latvanlehto, A.; Fox, M.A.; Sormunen, R.; Tu, H.; Oikarainen, T.; Koski, A.; Naumenko, N.; Shakirzyanova, A.; Kallio, M.; Ilves, M.; Giniatullin, R.; et al. Muscle-derived collagen XIII regulates maturation of the skeletal neuromuscular junction. J. Neurosci. 2010, 30, 12230-12241. [CrossRef] [PubMed]

45. Denzer, A.J.; Brandenberger, R.; Gesemann, M.; Chiquet, M.; Ruegg, M.A. Agrin Binds to the Nerve-Muscle Basal Lamina via Laminin. J. Cell Biol. 1997, 137, 671-683. [CrossRef] [PubMed]

46. Sugiyama, J.; Bowen, D.C.; Hall, Z.W. Dystroglycan Binds Nerve and Muscle Agrin. Neuron 1994, 13, $103-115$. [CrossRef]

47. Samuel, M.A.; Valdez, G.; Tapia, J.C.; Lichtman, J.W.; Sanes, J.R. Agrin and Synaptic Laminin Are Required to Maintain Adult Neuromuscular Junctions. PLos ONE 2012, 7. [CrossRef] [PubMed]

48. Ferns, M.; Deiner, M.; Hall, Z. Agrin-induced Acetylcholine Receptor Clustering in Mammalian Muscle Rexluires Tyrosine Phosphorylation. J. Cell Biol. 1996, 132, 937-944. [CrossRef] [PubMed]

49. Arikawa-hirasawa, E.; Rossi, S.G.; Rotundo, R.L.; Yamada, Y. Absence of acetylcholinesterase at the neuromuscular junctions of perlecan-null mice. Nat. Neurosci. 2002. [CrossRef] [PubMed]

50. Peng, H.B.; Ali, A.; Dagget, D.; Rauvala, H.; Hassell, J.; Smalheiser, N. The relationship between perlecan and dystroglycan and its implication in the formation of the neuromuscular junction. Cell Adhes. Commun. 1998, 5, 475-489. [CrossRef] [PubMed]

51. Ohno, K.; Brengman, J.; Tsujino, A.; Engel, A.G. Human endplate acetylcholinesterase deficiency caused by mutations in the collagen-like tail subunit (ColQ) of the asymmetric enzyme. Proc. Natl. Acad. Sci. USA 1998, 95, 9654-9659. [CrossRef] [PubMed]

52. Legay, C. Congenital myasthenic syndromes with acetylcholinesterase deficiency, the pathophysiological mechanisms. Ann. N. Y. Acad. Sci. 2018, 1413, 104-110. [CrossRef] [PubMed] 
53. Cartaud, A.; Strochlic, L.; Guerra, M.; Blanchard, B.; Lambergeon, M.; Krejci, E.; Cartaud, J.; Legay, C. MuSK is required for anchoring acetylcholinesterase at the neuromuscular junction. J. Cell Biol. 2004, 165, 505-515. [CrossRef] [PubMed]

54. Mihaylova, V.; Müller, J.S.; Vilchez, J.J.; Salih, M.A.; Kabiraj, M.M.; D’Amico, A.; Bertini, E.; Wölfle, J.; Schreiner, F.; Kurlemann, G.; Rasic, V.M.; et al. Clinical and molecular genetic findings in COLQ-mutant congenital myasthenic syndromes. Brain 2008, 131, 747-759. [CrossRef] [PubMed]

55. Hutchinson, D.O.; Walls, T.J.; Nakano, S.; Camp, S.; Taylor, P.; Harper, C.M.; Groover, R.V.; Peterson, H.A.; Jamieson, D.G.; Engel, A.G. Congenital endplate acetylcholinesterase deficiency. Brain 1993, 116, $633-653$. [CrossRef] [PubMed]

56. Bestue-Cardiel, M.; Sáenz de Cabezón-Alvarez, A.; Capablo-Liesa, J.L.; López-Pisón, J.; Peña-Segura, J.L.; Martin-Martinez, J.; Engel, A.G. Congenital endplate acetylcholinesterase deficiency responsive to ephedrine. Neurology 2005, 65, 144-146. [CrossRef] [PubMed]

57. Nykvist, P.; Tu, H.; Ivaska, J.; Ka, J.; Pihlajaniemi, T. Distinct Recognition of Collagen Subtypes by $\alpha 1 \beta 1$ and $\alpha 2 \beta 1$ Integrins. J. Biol. Chem. 2000, 275, 8255-8261. [CrossRef] [PubMed]

58. Tu, H.; Sasaki, T.; Snellman, A.; Göhring, W.; Pirilä, P.I.; Timpl, R.; Pihlajaniemi, T. The type XIII collagen ectodomain is a 150-nm rod and capable of binding to fibronectin, nidogen-2, perlecan, and heparin. J. Biol. Chem. 2002, 277, 23092-23099. [CrossRef] [PubMed]

59. Logan, C.V.; Cossins, J.; Rodríguez Cruz, P.M.; Parry, D.A.; Maxwell, S.; Martínez-Martínez, P.; Riepsaame, J.; Abdelhamed, Z.A.; Lake, A.V.R.; Moran, M.; et al. Congenital Myasthenic Syndrome Type 19 Is Caused by Mutations in COL13A1, Encoding the Atypical Non-fibrillar Collagen Type XIII $\alpha 1$ Chain. Am. J. Hum. Genet. 2015, 97, 878-885. [CrossRef] [PubMed]

60. Maselli, R.A.; Ng, J.J.; Anderson, J.A.; Cagney, O.; Arredondo, J.; Williams, C.; Wessel, H.B.; Abdel-Hamid, H.; Wollmann, R.L. Mutations in LAMB2 causing a severe form of synaptic congenital myasthenic syndrome. J. Med. Genet. 2009, 46, 203-208. [CrossRef] [PubMed]

61. Zenker, M.; Aigner, T.; Wendler, O.; Tralau, T.; Mu, H.; Royer-pokora, B.; Wu, E.; Fenski, R.; Pitz, S.; Cochat, P.; et al. Human laminin b 2 deficiency causes congenital nephrosis with mesangial sclerosis and distinct eye abnormalities. Hum. Mol. Genet. 2004, 13, 2625-2632. [CrossRef] [PubMed]

62. Maselli, R.A.; Chong, J.X.; Arredondo, J.; Vázquez, J.; Bamshad, M.J.; Nickerson, D.A.; Lara, M.; Ng, F.; Lo, V.L.; Pytel, P.; Mcdonald, C.M. Presynaptic congenital myasthenic syndrome with a homozygous sequence variant in LAMA5 combines myopia, facial tics, and failure of neuromuscular transmission. Am. J. Med. Genet. Part A 2017, 2240-2245. [CrossRef] [PubMed]

63. Vincent, A.; Newson-Davis, J.; Wray, D.; Shillito, P.; Harrison, J.; Betty, B.; Beeson, D.; Mills, K.; Palace, J.; Molenaar, P.; et al. Clinical and Experimental Observations in Patients with Congenital Myasthenic Syndromes. Ann. N. Y. Acad. Sci. 1993, 681, 451-460. [CrossRef] [PubMed]

64. Burke, G.; Cossins, J.; Maxwell, S.; Robb, S.; Nicolle, M.; Vincent, A.; Newson-Davis, J.; Palace, J.; Beeson, D. Distinct phenotypes of congenital acetylcholine receptor deficiency. Neuromuscul. Disord. 2004, 14, 356-364. [CrossRef] [PubMed]

65. Abicht, A.; Müller, J.S.; Lochmüller, H. Congenital Myasthenic Syndromes; Pagon, R., Adam, M., Ardinger, H., Eds.; University of Washington: Seattle, WA, USA, 2016.

66. Cossins, J.; Webster, R.; Maxwell, S.; Burke, G.; Vincent, A.; Beeson, D. A mouse model of AChR deficiency syndrome with a phenotype reflecting the human condition. Hum. Mol. Genet. 2004, 13, 2947-2957. [CrossRef] [PubMed]

67. Engel, A.G. The Therapy of Congenital Myasthenic Syndromes. Neurotherapeutics 2007, 4, 252-257. [CrossRef] [PubMed]

68. Rodríguez Cruz, P.M.; Palace, J.; Ramjattan, H.; Robb, S.A.; Beeson, D. Salbutamol and ephedrine in the treatment of severe AChR-deficiency syndromes. Neurology 2015, 85, 1-5. [CrossRef] [PubMed]

69. Ohno, K.; Hutchinson, D.; Milone, M.; Brengman, J.M.; Bouzatt, C.; Sinet, S.M.; Engel, A.G. Congenital myasthenic syndrome caused by prolonged acetylcholine receptor channel openings due to a mutation in the M2 domain of the E subunit. Proc. Natl. Acad. Sci. USA 1995, 92, 758-762. [CrossRef] [PubMed]

70. Zhu, H.; Pytel, P.; Gomez, C.M. Selective inhibition of caspases in skeletal muscle reverses the apoptotic synaptic degeneration in slow-channel myasthenic syndrome. Hum. Mol. Genet. 2014, 23, 69-77. [CrossRef] [PubMed] 
71. Chaouch, A.; Müller, J.S.; Guergueltcheva, V.; Dusl, M.; Schara, U.; Rakocević-Stojanović, V.; Lindberg, C.; Scola, R.H.; Werneck, L.C.; Colomer, J.; et al. A retrospective clinical study of the treatment of slow-channel congenital myasthenic syndrome. J. Neurol. 2012, 259, 474-481. [CrossRef] [PubMed]

72. Ohno, K.; Wang, H.; Milone, M.; Bren, N.; Brengman, J.M.; Nakano, S.; Quiram, P.; Pruitt, J.N.; Sine, S.M.; Engel, A.G. Congenital Myasthenic Syndrome Caused by Decreased Agonist Binding Affinity Due to a Mutation in the Acetylcholine Receptor epsilon Subunit. Neuron 1996, 17, 157-170. [CrossRef]

73. Palace, J.; Lashley, D.; Bailey, S.; Jayawant, S.; Carr, A.; McConville, J.; Robb, S.; Beeson, D. Clinical features in a series of fast channel congenital myasthenia syndrome. Neuromuscul. Disord. 2012, 22, 112-117. [CrossRef] [PubMed]

74. Sine, S.M.; Wang, H.; Shen, X.-M.; Lee, W.Y.; Engel, A.G. Mechanistic diversity underlying fast channel congenital myasthenic syndrome. Ann. N. Y. Acad. Sci. 2003, 998, 128-137. [CrossRef] [PubMed]

75. Wu, H.; Xiong, W.C.; Mei, L. To build a synapse: Signaling pathways in neuromuscular junction assembly. Development 2010, 1033, 1017-1033. [CrossRef] [PubMed]

76. Kim, N.; Stiegler, A.L.; Cameron, T.O.; Hallock, P.T.; Gomez, A.M.; Huang, J.H.; Hubbard, S.R.; Dustin, M.L.; Burden, S.J. Lrp4 Is a Receptor for Agrin and Forms a Complex with MuSK. Cell 2008, 135, 334-342. [CrossRef] [PubMed]

77. Burden, S.J.; Yumoto, N.; Zhang, W. The role of MuSK in synapse formation and neuromuscular disease. Cold Spring Harb. Perspect. Biol. 2013, 5, 1-11. [CrossRef] [PubMed]

78. Hallock, P.T.; Xu, C.; Park, T.; Neubert, T.A.; Curran, T.; Burden, S.J. Dok-7 regulates neuromuscular synapse formation by recruiting Crk and Crk-L. Genes Dev. 2010, 24, 2451-2461. [CrossRef] [PubMed]

79. Luo, Z.G.; Wang, Q.; Zhou, J.Z.; Wang, J.; Luo, Z.; Liu, M.; He, X.; Wynshaw-boris, A.; Xiong, W.C.; Lu, B.; Mei, L. Regulation of AChR Clustering by Dishevelled Interacting with MuSK and PAK1. Neuron 2002, 35, 489-505. [CrossRef]

80. Henriquez, J.P.; Webb, A.; Bence, M.; Bildsoe, H.; Sahores, M.; Hughes, S.M.; Salinas, P.C. Wnt signaling promotes AChR aggregation at the neuromuscular synapse in collaboration with agrin. Proc. Natl. Acad. Sci. USA 2008, 105, 2-7. [CrossRef] [PubMed]

81. Lin, W.; Dominguez, B.; Yang, J.; Aryal, P.; Brandon, E.P.; Gage, F.H.; Lee, K.F. Neurotransmitter acetylcholine negatively regulates neuromuscular synapse formation by a Cdk5-dependent mechanism. Neuron 2005, 46, 569-579. [CrossRef] [PubMed]

82. Chen, F.; Qian, L.; Yang, Z.; Huang, Y.; Ngo, S.T.; Ruan, N.; Wang, J.; Schneider, C.; Noakes, P.G.; Ding, Y.; et al. Rapsyn Interaction with Calpain Stabilizes AChR Clusters at the Neuromuscular Junction. Neuron 2007, 55, 247-260. [CrossRef] [PubMed]

83. Patrick, G.N.; Zukerberg, L.; Nikolic, M.; de la Monte, S.; Dikkes, P.; Tsai, L.-H. Conversion of p35 to p25 deregulates Cdk5 activity and promotes neurodegeneration. Nature 1999, 402, 615-622. [CrossRef] [PubMed]

84. Maselli, R.A.; Fernandez, J.M.; Arredondo, J.; Navarro, C.; Ngo, M.; Beeson, D.; Cagney, Ó.; Williams, D.C.; Wollmann, R.L.; Ferns, V.Y.M.J. LG2 agrin mutation causing severe congenital myasthenic syndrome mimics functional characteristics of non-neural (z-) agrin. Hum. Genet. 2012, 1123-1135. [CrossRef] [PubMed]

85. Richard, P.; Goillot, E.; Huze, C.; Gaudon, K.; Ammar, A.B.; Chaboud, A.; Grosjean, I.; Lecuyer, H.; Koenig, J.; Fournier, E.; et al. Identification of an Agrin Mutation that Causes Congenital Myasthenia and Affects Synapse Function. Am. J. Hum. Genet. 2009, 155-167. [CrossRef]

86. Xi, J.; Yan, C.; Liu, W.W.; Qiao, K.; Lin, J.; Tian, X.; Wu, H.; Lu, J.; Wong, L.J.; Beeson, D.; et al. Novel SEA and LG2 Agrin mutations causing congenital Myasthenic syndrome. Orphanet J. Rare Dis. 2017, 12, 1-7. [CrossRef] [PubMed]

87. Karakaya, M.; Ceyhan-Birsoy, O.; Beggs, A.H.; Topaloglu, H. A novel missense variant in the AGRN gene; congenital myasthenic syndrome presenting with head drop. J. Clin. Neuromuscul. Dis. 2017, 18, 147-151. [CrossRef] [PubMed]

88. Nicole, S.; Chaouch, A.; Torbergsen, T.; Bauché, S.; de Bruyckere, E.; Fontenille, M.-J.; Horn, M.A.; van Ghelue, M.; Løseth, S.; Issop, Y.; Cox, D.; et al. Agrin mutations lead to a congenital myasthenic syndrome with distal muscle weakness and atrophy. Brain 2014, 137, 2429-2443. [CrossRef] [PubMed]

89. Zhang, W.; Coldefy, A.-S.; Hubbard, S.R.; Burden, S.J. Agrin binds to the N-terminal region of Lrp4 protein and stimulates association between Lrp4 and the first immunoglobulin-like domain in muscle-specific kinase (MuSK). J. Biol. Chem. 2011, 286, 40624-40630. [CrossRef] [PubMed] 
90. Ohkawara, B.; Cabrera-Serrano, M.; Nakata, T.; Milone, M.; Asai, N.; Ito, K.; Ito, M.; Masuda, A.; Ito, Y.; Engel, A.G.; et al. LRP4 third $\beta$-propeller domain mutations cause novel congenital myasthenia by compromising agrin-mediated MuSK signaling in a position-specific manner. Hum. Mol. Genet. 2013. [CrossRef] [PubMed]

91. Selcen, D.; Ohkawara, B.; Shen, X.-M.; McEvoy, K.; Ohno, K.; Engel, A.G. Impaired Synaptic Development, Maintenance, and Neuromuscular Transmission in LRP4-Related Myasthenia. JAMA Neurol. 2015, 72, 889-896. [CrossRef] [PubMed]

92. DeChiara, T.M.; Bowen, D.C.; Valenzuela, D.M.; Simmons, M.V.; Poueymirou, W.T.; Thomas, S.; Kinetz, E.; Compton, D.L.; Rojas, E.; Park, J.S.; et al. The receptor tyrosine kinase MuSK is required for neuromuscular junction formation in vivo. Cell 1996, 85, 501-512. [CrossRef]

93. Chevessier, F.; Faraut, B.; Ravel-Chapuis, A.; Richard, P.; Gaudon, K.; Bauché, S.; Prioleau, C.; Herbst, R.; Goillot, E.; Ioos, C.; et al. MUSK, a new target for mutations causing congenital myasthenic syndrome. Hum. Mol. Genet. 2004, 13, 3229-3240. [CrossRef] [PubMed]

94. Maselli, R.A.; Arredondo, J.; Cagney, O.; Ng, J.J.; Anderson, J.A.; Williams, C.; Gerke, B.J.; Soliven, B.; Wollmann, R.L. Mutations in MUSK causing congenital myasthenic syndrome impair MuSK-Dok-7 interaction. Hum. Mol. Genet. 2010, 19, 2370-2379. [CrossRef] [PubMed]

95. Ammar, A.B.; Soltanzadeh, P.; Bauché, S.; Richard, P.; Goillot, E.; Herbst, R.; Gaudon, K.; Huze, C.; Schaeffer, L.; Yamanashi, Y.; et al. A Mutation Causes MuSK Reduced Sensitivity to Agrin and Congenital Myasthenia. PLoS ONE 2013, 8. [CrossRef]

96. Owen, D.; Töpf, A.; Preethish-Kumar, V.; Lorenzoni, P.J.; Vroling, B.; Scola, R.H.; Dias-Tosta, E.; Geraldo, A.; Polavarapu, K.; Nashi, S.; et al. Recessive variants of MuSK are associated with late onset CMS and predominant limb girdle weakness. Am. J. Med. Genet. Part A 2018, 1-8. [CrossRef] [PubMed]

97. Okada, K.; Inoue, A.; Okada, M.; Murata, Y.; Kakuta, S.; Jigami, T.; Kubo, S.; Shiraishi, H.; Eguchi, K.; Motomura, M.; et al. The muscle protein Dok-7 is essential for neuromuscular synaptogenesis. Science 2006, 312, 1802-1805. [CrossRef] [PubMed]

98. Beeson, D.; Higuchi, O.; Palace, J.; Cossins, J.; Spearman, H.; Maxwell, S.; Newsom-Davis, J.; Burke, G.; Fawcett, P.; Motomura, M.; et al. Dok-7 mutations underlie a neuromuscular junction synaptopathy. Science 2006, 313, 1975-1978. [CrossRef] [PubMed]

99. Cossins, J.; Liu, W.W.; Belaya, K.; Maxwell, S.; Oldridge, M.; Lester, T.; Robb, S.; Beeson, D. The spectrum of mutations that underlie the neuromuscular junction synaptopathy in DOK7 congenital myasthenic syndrome. Hum. Mol. Genet. 2012, 21, 3765-3775. [CrossRef] [PubMed]

100. Palace, J.; Lashley, D.; Newsom-davis, J.; Cossins, J.; Maxwell, S.; Kennett, R.; Jayawant, S.; Yamanashi, Y.; Beeson, D. Clinical features of the DOK7 neuromuscular junction synaptopathy. Brain 2007, 130, 1507-1515. [CrossRef] [PubMed]

101. Lashley, D.; Palace, J.; Jayawant, S.; Robb, S.; Beeson, D. Ephedrine treatment in congenital myasthenic syndrome due to mutations in DOK7. Neurology 2010, 74, 1517-1523. [CrossRef] [PubMed]

102. Sobel, A.; Weber, M.; JP, C. Large-Scale Purification of the Acetylcholine-Receptor Protein in Its Membrane-Bound and Detergent -Ext ract ed Forms from. Eur. J. Biochem. 1977, 80, 215-224. [CrossRef] [PubMed]

103. Gautam, M.; Noakes, P.G.; Mudd, J.; Nichol, M.; Chu, G.C.; Sanes, J.R.; Merlie, J.P. Failure of postsynaptic specialization to develop at neuromuscular junctions of rapsyn-deficient mice. Nature 1995, 377, 232-236. [CrossRef] [PubMed]

104. Moransard, M.; Borges, L.S.; Willmann, R.; Marangi, P.A.; Brenner, H.R.; Ferns, M.J.; Fuhrer, C. Agrin Regulates Rapsyn Interaction with Surface Acetylcholine Receptors, and This Underlies Cytoskeletal Anchoring and Clustering. J. Biol. Chem. 2003, 278, 7350-7359. [CrossRef] [PubMed]

105. Apel, E.D.; Roberds, S.L.; Campbell, K.P.; Merlie, J.P. Rapsyn May Function as a Link between the Acetylcholine Receptor and the Agrin-Binding Glycoprotein Complex. Neuron 1995, 15, 115-126. [CrossRef]

106. Zuber, B.; Unwin, N. Structure and superorganization of acetylcholine receptor-rapsyn complexes. Proc. Natl. Acad. Sci. USA 2013, 110, 10622-10627. [CrossRef] [PubMed]

107. Ohno, K.; Engel, A.G.; Shen, X.-M.; Selcen, D.; Brengman, J.; Harper, C.M.; Tsujino, A.; Milone, M. Rapsyn mutations in humans cause endplate acetylcholine-receptor deficiency and myasthenic syndrome. Am. J. Hum. Genet. 2002, 70, 875-885. [CrossRef] [PubMed] 
108. Cossins, J.; Burke, G.; Maxwell, S.; Spearman, H.; Man, S.; Kuks, J.; Vincent, A.; Palace, J.; Fuhrer, C.; Beeson, D. Diverse molecular mechanisms involved in AChR deficiency due to rapsyn mutations. Brain 2006, 129, 2773-2783. [CrossRef] [PubMed]

109. Burke, G.; Cossins, J.; Maxwell, S.; Owens, G.; Vincent, A.; Robb, S.; Nicolle, M.; Jones, D.H.; Davis, J.N.; Palace, J.; et al. Rapsyn mutations in hereditary myasthenia Distinct early- and late-onset phenotypes. Neurology 2003. [CrossRef]

110. Milone, M.; Shen, X.M.; Selcen, D.; Ohno, K.; Brengman, J.; Iannaccone, S.T.; Harper, C.M.; Engel, A.G. Myasthenic syndrome due to defects in rapsyn: Clinical and molecular findings in 39 patients. Neurology 2009, 73, 228-235. [CrossRef] [PubMed]

111. Vogt, J.; Harrison, B.J.; Spearman, H.; Cossins, J.; Vermeer, S.; Naudin, L.; Morgan, N.V.; Beeson, D.; Maher, E.R. Mutation Analysis of CHRNA1, CHRNB1, CHRND, and RAPSN Genes in Multiple Pterygium Syndrome/Fetal Akinesia Patients. Am. J. Hum. Genet. 2008, 88, 222-227. [CrossRef] [PubMed]

112. Natera-de Benito, D.; Bestué, M.; Vilchez, J.J.; Evangelista, T.; Töpf, A.; García-ribes, A. Long-term follow-up in patients with congenital myasthenic syndrome due to RAPSN mutations. Neuromuscul. Disord. 2016, 26, 153-159. [CrossRef] [PubMed]

113. Jaeken, J.; Matthijs, G. Congenital disorders of glycosylation. Annu. Rev. Genom. Hum. Genet. 2001, 2, 129-151. [CrossRef] [PubMed]

114. Wu, X.; Rush, J.S.; Karaoglu, D.; Krasnewich, D.; Lubinsky, M.S.; Waechter, C.J.; Gilmore, R.; Freeze, H.H. Deficiency of UDP-GlcNAc:Dolichol Phosphate N-Acetylglucosamine-1 Phosphate Transferase (DPAGT1) causes a novel congenital disorder of Glycosylation Type Ij. Hum. Mutat. 2003, 22, 144-150. [CrossRef] [PubMed]

115. Thiel, C.; Schwarz, M.; Peng, J.; Grzmil, M.; Hasilik, M.; Braulke, T.; Kohlschütter, A.; von Figura, K.; Lehle, L.; Körner, C. A new type of congenital disorders of glycosylation (CDG-Ii) provides new insights into the early steps of dolichol-linked oligosaccharide biosynthesis. J. Biol. Chem. 2003, 278, 22498-22505. [CrossRef] [PubMed]

116. Belaya, K.; Finlayson, S.; Cossins, J.; Liu, W.W.; Maxwell, S.; Palace, J.; Beeson, D. Identification of DPAGT1 as a new gene in which mutations cause a congenital myasthenic syndrome. Ann. N. Y. Acad. Sci. 2012, 1275, 29-35. [CrossRef] [PubMed]

117. Senderek, J.; Müller, J.S.; Dusl, M.; Strom, T.M.; Guergueltcheva, V.; Diepolder, I.; Laval, S.H.; Maxwell, S.; Cossins, J.; Krause, S.; et al. Hexosamine biosynthetic pathway mutations cause neuromuscular transmission defect. Am. J. Hum. Genet. 2011, 88, 162-172. [CrossRef] [PubMed]

118. Cossins, J.; Belaya, K.; Hicks, D.; Salih, M.A.; Finlayson, S.; Carboni, N.; Liu, W.W.; Maxwell, S.; Zoltowska, K.; Farsani, G.T.; Laval, S.; et al. Congenital myasthenic syndromes due to mutations in ALG2 and ALG14. Brain 2013, 136, 944-956. [CrossRef] [PubMed]

119. Gehle, V.M.; Walcott, E.C.; Nishizaki, T.; Sumikawa, K. N-glycosylation at the conserved sites ensures the expression of properly folded functional ACh receptors. Brain Res. Mol. Brain Res. 1997, 45, $219-229$. [CrossRef]

120. Zoltowska, K.; Webster, R.; Finlayson, S.; Maxwell, S.; Cossins, J.; Müller, J.; Lochmüller, H.; Beeson, D. Mutations in GFPT1 that underlie limb-girdle congenital myasthenic syndrome result in reduced cell-surface expression of muscle AChR. Hum. Mol. Genet. 2013, 22, 2905-2913. [CrossRef] [PubMed]

121. Haltiwanger, R.S.; Lowe, J.B. Role of glycosylation in development. Annu. Rev. Biochem. 2004, 73, 491-537. [CrossRef] [PubMed]

122. Selcen, D.; Shen, X.-M.; Milone, M.; Brengman, J.; Ohno, K.; Deymeer, F.; Finkel, R.; Rowin, J.; Engel, A.G. GFPT1-myasthenia: Clinical, structural, and electrophysiologic heterogeneity. Neurology 2013, 81, 370-378. [CrossRef] [PubMed]

123. Bauché, S.; Vellieux, G.; Sternberg, D.; Fontenille, M.J.; Bruyckere, E. De; Sophie, C.; Guy, D.; Messéant, J.; Wolf, L.; Fardeau, M.; Lacène, E.; et al. Mutations in GFPT1-related congenital myasthenic syndromes are associated with synaptic morphological defects and underlie a tubular aggregate myopathy with synaptopathy. J. Neurol. 2017, 264, 1791-1803. [CrossRef] [PubMed]

124. Huh, S.-Y.; Kim, H.-S.; Jang, H.-J.; Park, Y.-E.; Kim, D.-S. Limb-girdle myasthenia with tubular aggregates associated with novel GFPT1 mutations. Muscle Nerve 2012, 46, 600-604. [CrossRef] [PubMed] 
125. Guergueltcheva, V.; Müller, J.S.; Dusl, M.; Senderek, J.; Oldfors, A.; Lindbergh, C.; Maxwell, S.; Colomer, J.; Mallebrera, C.J.; Nascimento, A.; et al. Congenital myasthenic syndrome with tubular aggregates caused by GFPT1 mutations. J. Neurol. 2012, 259, 838-850. [CrossRef] [PubMed]

126. Bretthauer, R.K. Structure, expression, and regulation of UDP-GlcNAc: Dolichol phosphate GlcNAc-1-phosphate transferase (DPAGT1). Curr. Drug Targets 2009, 10, 477-482. [CrossRef] [PubMed]

127. Basiri, K.; Belaya, K.; Liu, W.W.; Maxwell, S.; Sedghi, M.; Beeson, D. Clinical features in a large Iranian family with a limb-girdle congenital myasthenic syndrome due to a mutation in DPAGT1. Neuromuscul. Disord. 2013, 23, 469-472. [CrossRef] [PubMed]

128. Selcen, D.; Shen, X.; Brengman, J.; Li, Y.; Stans, A.A.; Wieben, E.; Engel, A. DPAGT1 myasthenia and myopathy: Genetic, phenotypic, and expression studies. Neurology 2014, 82, 1822-1830. [CrossRef] [PubMed]

129. Belaya, K.; Finlayson, S.; Slater, C.R.; Cossins, J.; Liu, W.W.; Maxwell, S.; McGowan, S.J.; Maslau, S.; Twigg, S.R.F.; Walls, T.J.; et al. Mutations in DPAGT1 cause a limb-girdle congenital myasthenic syndrome with tubular aggregates. Am. J. Hum. Genet. 2012, 91, 193-201. [CrossRef] [PubMed]

130. Finlayson, S.; Palace, J.; Belaya, K.; Walls, T.; Norwood, F.; Burke, G.; Holton, J.; Pascual-Pascual, S.; Cossins, J.; Beeson, D. Clinical features of congenital myasthenic syndrome due to mutations in DPAGT1. J. Neurol. Neurosurg. Psychiatry 2013, 84, 1119-1125. [CrossRef] [PubMed]

131. Lu, J.; Takahashi, T.; Ohoka, A.; Nakajima, K.; Hashimoto, R.; Miura, N.; Tachikawa, H.; Gao, X.-D. Alg14 organizes the formation of a multiglycosyltransferase complex involved in initiation of lipid-linked oligosaccharide biosynthesis. Glycobiology 2012, 22, 504-516. [CrossRef] [PubMed]

132. Jackson, B.J.; Kukuruzinska, M.A.; Robbins, P. Biosynthesis of asparagine-linked oligosaccharides in Saccharomyces cerevisiae: The alg2 mutation. Glycobiology 1993, 3, 357-364. [CrossRef] [PubMed]

133. Monies, D.M.; Al-Hindi, H.N.; Al-Muhaizea, M.A.; Jaroudi, D.J.; Al-Younes, B.; Naim, E.A.; Wakil, S.M.; Meyer, B.F.; Bohlega, S. Clinical and pathological heterogeneity of a congenital disorder of glycosylation manifesting as a myasthenic/myopathic syndrome. Neuromuscul. Disord. 2014. [CrossRef] [PubMed]

134. Muntoni, F.; Torelli, S.; Wells, D.J.; Brown, S.C. Muscular dystrophies due to glycosylation defects: Diagnosis and therapeutic strategies. Curr. Opin. Neurol. 2011, 24, 437-442. [CrossRef] [PubMed]

135. Belaya, K. Mutations in GMPPB cause congenital myasthenic syndrome and bridge myasthenic disorders with dystroglycanopathies. Brain 2015. [CrossRef] [PubMed]

136. Cruz, P.M.R.; Belaya, K.; Basiri, K.; Sedghi, M.; Farrugia, M.E.; Holton, J.L.; Liu, W.W.; Maxwell, S.; Petty, R.; Walls, T.J.; et al. Clinical features of the myasthenic syndrome arising from mutations in GMPPB. BMJ 2016, 1-8. [CrossRef]

137. Witting, N.; Vissing, J. Pharmacologic Treatment of Downstream of Tyrosine Kinase 7 Congenital Myasthenic Syndrome. JAMA Neurol. 2014, 1-5. [CrossRef] [PubMed]

138. Schwab, R.S.; Timberlake, W.H. Pyridostigmin (Mestinon) in the treatment of myasthenia gravis. N. Engl. J. Med. 1954, 251, 271-272. [CrossRef] [PubMed]

139. Palace, J.; Wiles, C.M.; Newsom-Davis, J. 3,4-Diaminopyridine in the treatment of congenital (hereditary) myasthenia. J. Neurol. Neurosurg. Psychiatry 1991, 54, 1069-1072. [CrossRef] [PubMed]

140. Harper, C.M.; Fukodome, T.; Engel, A.G. Treatment of slow-channel congenital myasthenic syndrome with fluoxetine. Neurology 2003, 60, 1710-1713. [CrossRef] [PubMed]

141. Burke, G.; Hiscock, A.; Klein, A.; Niks, E.H.; Main, M.; Manzur, A.Y.; Ng, J.; de Vile, C.; Muntoni, F.; Beeson, D.; et al. Salbutamol benefits children with congenital myasthenic syndrome due to DOK7 mutations. Neuromuscul. Disord. 2013, 23, 170-175. [CrossRef] [PubMed]

142. Lorenzoni, P.J.; Scola, R.H.; Kay, C.S.K.; Filla, L.; Miranda, A.P.P.; Pinheiro, J.M.R.; Chaouch, A.; Lochmüller, H.; Werneck, L.C. Salbutamol therapy in congenital myasthenic syndrome due to DOK7 mutation. J. Neurol. Sci. 2013, 331, 155-157. [CrossRef] [PubMed]

143. Liewluck, T.; Selcen, D.; Engel, A.G. Beneficial effects of Albuterol in congenital endplate acetylcholinesterase deficiency and DOK-7 myasthenia. Muscle Nerve 2011, 44, 789-794. [CrossRef] [PubMed]

(C) 2018 by the authors. Licensee MDPI, Basel, Switzerland. This article is an open access article distributed under the terms and conditions of the Creative Commons Attribution (CC BY) license (http:/ / creativecommons.org/licenses/by/4.0/). 